California Western School of Law

CWSL Scholarly Commons

Faculty Scholarship

2017

From Visualization to Legal Design: A Collaborative and Creative Process

Gerlinde Berger-Walliser

Thomas D. Barton

Helena Haapio

Follow this and additional works at: https://scholarlycommons.law.cwsl.edu/fs

Part of the Other Law Commons 


\title{
From Visualization to Legal Design: A Collaborative and Creative Process
}

\author{
Gerlinde Berger-Walliser,* Thomas D. Barton,** and \\ Helena Haapio***
}

\section{INTRODUCTION}

The digital revolution has prompted a strong and accelerating interest in "visualization"- the use of images, photos, icons, diagrams, charts, or videos to enhance or supplant printed language. 'Although the law

\footnotetext{
*Assistant Professor of Business Law, University of Connecticut, School of Business, Marketing Department, 2100 Hillside Road, Unit 1041, Storrs, CT 06269-1041, 860-4865864, gerlinde.berger-walliser (a) ucomn.edu.

**Professor of Law, California Western School of Law, 225 Cedar Street San Diego, CA 9210, tbarton@cwsl.edu.

***Associate Professor of Business Law, University of Vaasa; International Contract Counsel, Lexpert Ltd, Pohjoisranta 20, FI-00170 Helsinki, Finland, +358 91355800 , helena. haapio(alexpert.com. The authors are grateful to Robert C. Bird, Josephine Sandler Nelson, George Siedel, and the participants in the Symposium on the Preventive and Positive Roles of Law at the University of Michigan, Ross School of Business, June 25-26, 2015, for their helpful comments, and to Peter Anastasio and Leila Hamhoum for their editorial assistance.
}

\footnotetext{
'Professors Sherwin, Feigenson, and Spiesel describe these trends and their impact on Westem intellectual history. See Richard K. Sherwin et al, Law in the Digital Age: How Visual Communication Techologies Are Transforming the Practice, Theory, and Teaching of Law, 12 B.U. J. Sci. \& TE.(H. L. 227, 230 (2006) ("Digital technologies allow the pictures and words from which meanings are composed to be seamlessly modified and recombined in any fashion whatsoever, while the Internet allows practically anyone, anywhere, to disseminate meanings just about everywhere. The Enlightenment-era insistence upon essentialist foundations (whether exemplified by Locke's empiricism, Kant's rational categories, or other totalizing epistemologies) is being challenged by digital experience, which has helped to inspire an alternative model of knowledge and reality as a centerless and constantly morphing network of relations."). Seminal work regarding the impact of Information Age technologies on the legal system and legal interpretation appears in two books by $M$. Ethan Katsh. See M. Firhan Katsh, Law in a Digrial World (1995); M. Ethan Katsh, The Electronic: Mrida and the Transformation of Law (1989).
} 
remains predominately focused on the written word, the appeal of images to clarify and persuade suggests that legal visualization will be increasingly explored in research and legal practice in coming years. As Michael D. Murray writes, "socio-epistemic and law and society studies affirm that as modern culture becomes increasingly visual, discourse of every kind must follow suit."2

Pioneering visualization studies have been groundbreaking and expansive. ${ }^{3}$ Murray provides a helpful overview of many vectors that contribute to the understanding and growing use of visualization: "the scholarship of popular culture, cognitive studies and brain science, data visualization studies, modern argument theory in rhetoric, the rapid development of technology in the production of documents, and technology in the reading and reception of documents."

\footnotetext{
${ }^{2}$ Michael D. Murray, Leaping Language and Cultural Barriers with Visual Legal Rhetoric, $49 \mathrm{U}$. Sax Friveisco L. RFx: F. 61, 68 (2015); see also Fred Galves, Will Video Kill the Radio Star? I'isual Learning and the Use of Display Technology in the Law School Classroom, 2004 U. I..L. J.L. Tre:H. \& Poly 195, 198 (discussing the use of display techniques in teaching today's law students who "are more accustomed to receiving information visually than students of the past"): Elizabeth (. Porter, Taking Images Seriously, 114 Col.l M. L. Rfx: 1687, 1693 (2014) (suggesting that "[u]nless courts specifically prohibit [visualization], [it] will become the norm" in legal communication and argument; and describing "multimedia written advocacy" as "the vernacular of modern communication" "[ $t]$ o rising generations of young lawyers"). For a discussion on the potential for using visualization techniques in private contracting, see, for example. Thomas D. Barton et al., Visualization: Seping Contracts for What They Are, and What They Could Become, 19 J.L. Bu's. \& Errics 47, 47-48 (2013); Helena Haapio, Lauryers as Designers, Engineers, and Innowators: Better Legal Documents Through Information Design and Visualization, in Transparencis: Procefoingss of The. 17th Internation. A. Lfant Infokmatics Simpostcm 551 (Erich Schweighofer et al. eds.. 2014), http://ssrn. com/abstract $=2651066$.
}

${ }^{3}$ See the highly generative work of Sherwin et al., supra note 1 . As will be noted throughout the article, those authors have continued to expand and refine their analysis and have been joined by many other insightful authors. Among many important recent works are Colette R. Brunschwig, Law Is Not or Must Not Be Just Verbal and Visual in the 21st Century: Toulard Multisensory Law, in Nordic: YeakboOK OF LAW AND INFORMatics 2010-2012: InTERNAtionalisation of Lan in thr. Digmal. Information Society 231 (Dan Jerker B. Svantesson \& Stanley Greenstein eds., 2012); Tobias Mahler, A Graphical User-Interface for Legal Texts?,

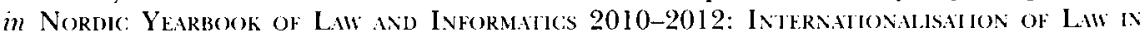
the Dicital. Information Soctety, supra, at 311 ; Jay A. Mitchell, Putting Some Product into Work-Product: Corporate Latyers Learning from Designers, 12 Berkeley BLs. L.J. 1 (2015); Murray, supra note 2; Porter, supra note 2; Richard K. Sherwin, Visual Jurisprudence, 57 N.Y. L. ScH. L. Rrv. 11 (2013); Rebecca Tushnet, Worth a Thousand Words: The Images of Copyright, 125 HaRv. L. Rev. 683 (2012).

${ }^{4}$ Murray, supra note 2, at 64 . 
more psychological or philosophical, analyzing images distinctly from words." These contributions contrast the cognitive processing, emotional impacts, or sociological implications of pictures with texts, and they help explain the potential benefits and dangers of "visual law" in the digital age. ${ }^{6}$ Other studies examine how images might function within traditional legal systems, focusing on how they may be used persuasively within litigation. ${ }^{7}$

Given the extent to which technology is advancing, permitting a range of legal visualizations to enter both legal research and practice, this article explores this evolving field with a focus on the process of visualization development, rather than the product-the image itself. The article contributes to the existing literature on legal visualization in multiple ways: first, it offers guidelines for using images in conjunction with words, rather than in isolation, as much of the cognitive-oriented legal visualization research suggests. Realistically, legal visualization is almost

\footnotetext{
${ }^{5}$ See generally, e.g., Colıx Warf., Vistiat. Thinking; for Design (2008); Clay Calvert, Every Picture Tells a Story, Don't It? Wrestling with the Complex Relationship Among Pholographs, Words and Newsurthiness in Journalistic Storytelling, 33 Coltm. J.L. \&. Akis 349 (2010); Lucille A. Jewel, Through a Glass Darkly: Using Brain Science and Visual Rhetoric to Gain a Professional Perspective on Visual Adrocacy, 19 S. Cal. INTERdisc. L.J. 237 (2010); Matthew J. McCloskey, Visualizing the Law: Methods for Mapping the Legal Landscape and Drawing Analogies, 73 WasH. L. Rev. 163 (1998); Murray, supra note 2; Porter, supra note 2; Sherwin et al., supra note 1; see also Nancy Illman Meyers, Paining the Law, 14 Cindozo ArTs \& ENT. L.J. 397, 398 (1996); Gila Safran Naveh, Glimmerings of the Gallows: Representing the Holocaust in Film and Fiction, 28 T. Jurierson L. Rev. 29, 31 (2005).
}

\footnotetext{
${ }^{6}$ See generally Richard K. Sherwin, Vistahtrinc: Law in the Adie or Digimal Babogele: Arabesqees and ENIAndifments (2011); [hereinafter Suerwin, Viscalizinci Law]; Murray, supra note 2; Sherwin et al., supra note 1. For a discussion on potential dangers of visualization, see Hampton Dellinger, Words Are Enough: The Troublesome Use of Photographs, Maps, and Other Images in Supreme Court Opinions, 110 H.ıkv. L. Rev. 1704 (1997); Porter, supra note 2, at 1752-53 (identifying "three primary dangers of welcoming images into the legal-writing toolbox: the lack of legal rules or traditions to mitigate the interpretive risks associated with images; the related potential for visual arguments to warp traditional allocations of decision-making power; and finally, the risk that image-driven legal argument will vitiate the intellectual vigor and civility of legal discourse"); Tushnet, supra note 3, at 695 ("Images are dangerous precisely because they seem so real."); see also Richaro K. SHer. win, Whin law Gofs Pop: The Vanishing; lanf. Beitween Law and Popliak Cititike 146 (2000).

${ }^{7}$ See generally, e.g., Sherwin, Visladizinc; Law, supra note 6; Dellinger, supra note 6; Ellen P. Goodman, Visual Gut Punch: Persuasion, Emotion, and the Constitutional Meaning of Graphic Disclosure, 99 Connitit. L. Rev. 513 (2014); K. Preston Oade \& Leslie C. Annand, Winning with Visual Fvidence, 25 Colo. LAw. 35 (1996); Porter, supra note 2; Tushnet, supra note 3.
} 
always used in hybrid ways - combinations of words and images to enhance the effectiveness of communication. That seems unlikely to change, given the need for detail and refinement when the law imposes duties on people. Second, we examine the use of images in business documents and in statutes, rather than in advocacy, which is the focus of much of the "visual law" literature mentioned above. ${ }^{8}$ Moving away from adversarial settings permits us to illustrate the use of images in a broader range of practical legal applications. ${ }^{9}$ It also enables us to analyze the value of visualization as a means to enhance user experience and organizational effectiveness. ${ }^{10}$ Finally, we analyze variables surrounding choices and consequences about the process of generating, transmitting, and using images to accompany legal language, which we call "Legal Design." 11 Legal Design goes beyond visualization. While it includes the use of graphic communication tools, it is not limited to document design or visualization. Rather, it merges legal and design thinking. It includes using design methods and tools other than graphics for legal purposes. Legal Design focuses on the way in which visual tools are created and effectively used in a legal transaction or legislative drafting. Examining this dynamic can deepen our understanding of the information conveyed. It can also reveal the potential of Legal Design to create spillover value for businesses or regulatory agencies that

\footnotetext{
${ }^{8}$ See supra note 6 and accompanying text.

${ }^{9}$ As emphasized in Sherwin et al., supra note 1 , at 228 , "legal meaning is produced by the ways law is practiced."

${ }^{10}$ See Mitchell, supra note 3, at 8-9 (suggesting that documents should be created through more reflective process); see also Tim Brown \& Jocelyn Wyatt, Design Thinking for Social Innovation, 8 STANFord SOC. InNOVAIION REv. 31, 32-33 (2010), http://ssirorg/images/ articles/2010WI_Features_WyattBrown_New.pdf (describing design thinking as a deeply human-centered process).

${ }^{11}$ For information about the movement toward using design methods and tools in the legal context, see Brunschwig, supra note 3; Kevin Conboy, Diagramming Transactions: Some Modest Proposals and a Few Suggested Rules, 16 TENN. J. Bus. L. 91 (2014); Wolfgang Kahlig, Visualisierungstypologie des Deutschen Privatrechts, in JusLETTER IT 24 (2011) (in German, describing efforts to visualize the (Cerman Civil Code); Mark Szabo, Design Thinking in Legal Practice Management, Design Mgmt. Rev: Sept. 2010, at 44; Margarfil Hagan, http:// www.margarethagan.com (last visited May 2, 2016).
} 
employ the images' effectiveness in line with strategic and proactive approaches to lawyering and the law. ${ }^{12}$

We use the plain design version of the Canadian federal Employment Insurance $\mathrm{Act}^{13}$ as an introductory example. The Act was commissioned by the Canadian government to make regulation more accessible to the public. ${ }^{14}$ In collaboration with Human Resources Development and Justice Canada, a team of communication designers introduced a redesign, which included diagrams and an improved layout to make document navigation easier and to enhance citizens' understanding of the Act. ${ }^{15}$

${ }^{19}$ For an analysis of Legal Design from a Proactive Law perspective, see Stefania Passera et al., User-Friendly Contracting Tools-A Visual Guide to Facilitate Public

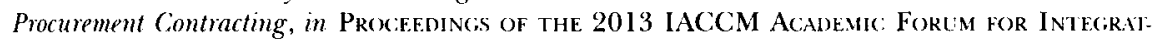
ing LaW and Contract Management: Proactive, Preventive and Sirategic: Approaches 74 (Jane Chittenden ed., 2013) [hereafter User-Friendly Tools]. See also Gerlinde Berger-Walliser et al., Promoting Business Success through Contract Visualization, 17 J. L. Bus. \& ErHics 55, $61-$ 65 (2011) (distinguishing traditional from proactive contracts). On the Proactive Law Movement, see Gerlinde Berger-Walliser, The Past and Future of Proactive Law: An Overniew of the Proactize Lazo Motement, in Proactive Law in a Businfss Envikonment 13 (Gerlinde Berger-Walliser \& Kim Østergaard eds., 2012); Gerlinde Berger-Walliser \& Paul Shrivastava, Beyond Complance: Sustainable Development, Business, and Proactive Law, 46 Gro. J. INT'L. L. 417, 434-39 (2015) (providing an overview of history and broad application of Proactive Law). See also, generally, Thomas D. Barton, Preventive Law ann Problem SolvING: LaWyering; for the Futurf (2009). For a comparison of Proactive Law and law and strategy in U.S. legal scholarship, see George J. Siedel \& Helena Haapio, Using Proactive Law for Competitive Advantage, 47 Am. Bus. L. J. 641 (2010). The value-creating role of law is also emphasized in the growing scholarship on law and strategy. See generally, e.g., Constance E. Bagley, What's Law Got to Do with It?: Integrating Law and Strategy, 47 AM. Bus. L.J. 587 (2010); Constance E. Bagley, Winning Legally: The Value of Legal Astuteness, 33 AcAD. Mgmt. Rfv. 378 (2008); Robert C. Bird \& David Orozco, Finding the Right Corporate Legal Strategy, 56 MIT Siodn Mcimr. Rr. 81 (2014); Robert C. Bird, Law, Strategy and Competitive Advantage, 44 Conn. L. RFv. 61 (2011); Robert C. Bird, Palhways of Legal Strategy, 14 STaN. J.L. Bus. \& Fin. 1 (2008).

${ }^{13}$ Employment Insurance Act, S.C. 1996, c 23 (Can.).

${ }^{14}$ David Berman, Toward a New Format for Canadian Legislation-Using Graphic Design Principles and Methods to Improve Public Access to the Law 14-15 (2000), https:/www. davidberman.com/NewFormat ForCanadianLegislation.pdf.

\footnotetext{
${ }^{15}$ For a sample of the new design, see $i d$. app. B. Testing revealed that respondents consistently rated the new design as "more user-friendly and effective at delivering information, engaging the reader and fostering an understanding of the Employment Insurance Act." Id. at 13. Preferences differed depending on the language and expertise of users. While only seventy-one percent of English language informed users preferred the new design over the old design, ninety-six percent of French language informed users preferred the new design version. $I d$. at 14 .
} 
The benefits of the new design are threefold. First, it is likely to reduce the time and effort citizens spend in contact with the government, thus improving user experience and communication, while freeing up resources for government administration. ${ }^{16}$ Second, the more userfriendly design sends a message that the government is concerned that citizens understand the Act, thereby enhancing the government's credibility and increasing the likelihood that people will engage with the legislation by communicating ideas to their elected representatives. ${ }^{17}$ Finally, the project report reveals that in the process of creating a flow chart diagram the design team discovered inconsistencies that were not accounted for in the current legislation. This suggests that if using diagrams becomes part of the process of legislative drafting, the resulting legislation might be substantively improved. ${ }^{18}$

As this example shows, good design and good processes not only enhance effectiveness in conveying information by improving accessibility, but also strengthen the functioning of the government agency that creates the legal document and, ultimately, the legal system as a whole. ${ }^{19}$ However, many working in the field have identified the need for a coherent methodology to control the use of legal design tools and techniques. ${ }^{20}$

This article responds to these calls for action. Part I outlines the concept of Legal Design. It first traces the development of design thinking within management studies by describing its characteristics and uneven application in business and legal contexts. It then identifies tensions between design thinking and traditional legal thinking. Finally, it transcends those tensions by integrating characteristics of Legal Design and value-driven legal approaches articulated in the literature on Preventive and Proactive Law.

Part II introduces and analyzes a framework for understanding and applying Legal Design. It provides a theory and set of best practices for

\footnotetext{
${ }^{16} I d$. at 31 .

${ }^{17}$ Id.

${ }^{18}$ See id. at 24.

${ }^{19}$ See id. at 31 (pointing toward the potential efficiency benefits for the organization and better citizen engagement).

${ }^{20}$ See generally, e.g., Jewel, supra note 5; Mahler, supra note 3; Porter, supra note 2; Sherwin et al., supra note 1; Sherwin, supra note 3.
} 
creating, communicating, and using images in conjunction with words in nonadversarial legal settings. The effective use of Legal Design offers much value to the business and legal community-it can spark collaboration and clear communication between various stakeholders and organizational units, and can supply benefits of innovation, creativity, and legal problem solving.

\section{Legal Design: An Evolution of Theory}

Common English language dictionaries define design as "the way something has been made: the way the parts of something (such as a building, machine, book, etc.) are formed and arranged for a particular use, effect, etc." ${ }^{21}$ Contrary to widespread ideas about design, this definition focuses on the process of creating something rather than the outcomethe finished product. "Design" is not primarily concerned with aesthetics or the "look of a product," nor is it restricted to movable or immovable objects such as machines, consumer goods, buildings, or works of art. Rather, design, or design thinking, is the underlying cognitive process of developing new ideas. ${ }^{22}$ As such, design is not concerned with how things are, but how they "ought to be," and professionals, such as architects, doctors, and managers, are expected to develop processes to reach this goal. ${ }^{23}$

\section{A. Management Perspectives: The Emergence of Design Thinking}

Design and design thinking have roots in several disciplines. ${ }^{24}$ For more than forty years, a stream of research called "designerly thinking"

\footnotetext{
${ }^{21}$ Design, Merriam-Webster Oni.ine Dicinonaks, http:/www.metriam-webster.com/dictionary/ design (last visited May 2, 2016).

${ }^{22}$ See Roy Glen et al., The Nepd for Design Thinking in Business Schools, 13 Acin. Mcimi: LERnicis \& EDtc. 653, 656 (2014) (defining design thinking as describing "cognitive processes designers have in common").

${ }^{23}$ See Lucy Kimbell, Rethinking Design Thinking: Part I, 3 Design \& Cliture: 285, 290-91 (2011); see also Richard J. Boland, Jr. et al, Managing as Designing: Lessons for Orgamization Leaders from the Design Practice of Frank O. Gehry, 24 Desicin Issues 10, 12 (2008) (both citing Herbert A. Simon, The Scilncis or thie Aktificial xii (3d ed. 1996)).

${ }^{24}$ See Ulla Johansson-Sköldberg et al., Design Thinking: Past, Present and Possible Futures, 22 Creativis \& InNovation Momi. 121, 132 (2013) (refusing to restrict design thinking to a single meaning in an attempt to uniquely define it).
} 
primarily addressed an academic understanding of what designers do and how this could be taught to students. ${ }^{25}$ It approached design from an interdisciplinary perspective influenced by economics, political science, ${ }^{26}$ philosophy, ${ }^{27}$ art history, design, and architecture, ${ }^{28}$ and concentrated on the professional designer and design as the creation of artifacts. $^{29}$ Others have analyzed design as a reflexive practice, ${ }^{30}$ problem-solving activity, ${ }^{31}$ or creation of meaning, ${ }^{32}$ and thus accessible and useful for any professional dealing with problem solving-not just professional designers. ${ }^{33}$ More recent "design thinking" is predominantly situated in management studies and mainly addresses individual cognition and organizational innovation. ${ }^{34}$ Though design continues to

"See id. at 123 (differentiating "designerly thinking" and design thinking; "designerly thinking" being defined as "the academic construction of the professional designer's practice," while design thinking is used to describe the application of a designer's methods by others outside the academic field of design).

${ }^{26}$ See generally Simon, supra note 23.

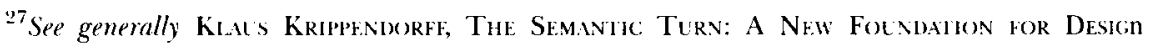
(2006); Domald A. Schón, The Reflective Practimoner: Hon Professionals Think in ACTION (1983).

${ }^{28}$ See generally Nigel Cross, Desigiterly Ways of Knowing (2006); Brian Lawson, How

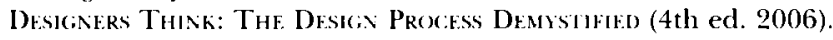

${ }^{29}$ See generally Simos, supra note 23.

${ }^{30}$ See generally ScHö, supra note 27.

${ }^{31}$ See generally Richard Buchanan, Wicked Problems in Design Thinking, 8 Desicin Isstes 22 (1992).

${ }^{32}$ See generally KRIPPENDORHF, supra note 27 . For a comparison of the different literature streams, see Johansson-Sköldberg et al., supra note 24, at 123-26.

${ }^{33}$ See Johansson-Sköldberg et al., supra note 24, at 127 (describing design thinking as "a way of thinking that non-designers can also use" (internal quotation marks omitted)).

${ }^{34}$ See Tim Brown, Design Thinking, 86 Harv. Bı's. Rrv. 84, 86 (2008) (defining design thinking as "a discipline that uses the designer's sensibility and methods to match people's needs with what is technologically feasible and... a viable business strategy which can [be] convert[ed] into customer value and market opportunity"); see also David Dunne \& Roger Martin, Design Thinking and Hou' It Will Change Management Education: An Interview and Discussion, 5 Acad. Mamt. Learning; \& Eotc., 512, 517-21 (2006) (explaining the concept of design thinking and exploring its potential to improve business school education); Johansson-Sköldberg et al., supra note 24, at 123; Kimbell, supra note 23, at 300-01 (positioning design thinking within a broader field of contemporary theory moving beyond anecdotal descriptions of what designers $d o$ ). 
involve form, objects, and visual representation, designing intangible services or experiences concentrates on developing rational procedures for solving problems that involve "decomposing systems as well as searching for and choosing alternatives." 35 If we look at design this way, it does not appear as a mere appendage or superficial concern about the "look" of a legal document. ${ }^{36}$ On the contrary, our vision for Legal Design advances the dialogue about how to address complex social or business concerns-in design-thinking terms, so-called wicked problems-in new ways that could become central for legal practice, scholarship, and education. ${ }^{37}$

\section{B. Characteristics of Design Thinking}

What characterizes design thinking depends on where, by whom, and for what purpose it is being used. The discourse thus varies significantly, depending on the disciplinary background of the author describing design thinking and the audience and goal the author seeks to address. ${ }^{38}$ Not all approaches are equally useful for application to legal theory and practice. Therefore, the following analysis concentrates on those characteristics and tools that translate best into the legal world, especially business law. ${ }^{39}$

\footnotetext{
${ }^{35}$ See Kimbell, supra note 23, at 290-91 (describing the fragmented nature of design as an academic discipline) (citing Christopher Alfxinider, Notfs on THE Sinthisis of Form (1964); Simon, supra note 23).

${ }^{36}$ See Ken Adams, Adding Document-Design Bling to Contracts, Adums on Contracic Draminc; (Dec. 1, 2011), http://www.adamsdrafting.com/adding-document-design-bling-to-contracts (arguing against "document-design embellishments," which he calls "document-design bling").

${ }^{37}$ See Hilary Collins, Can Design Thinking Still Add Value?, Design Mcimi: Rrv. June 2013, at 35, 36, 39 (citing Buchanan, supra note 31 ).

${ }^{38}$ For an analysis and classification of existing literature in design and management studies, see Johansson-Sköldberg et al., supra note 24 , app. A, at 136-44.

${ }^{393}$ The following characteristics largely draw on Glen et al., supra note 22, at 657-58 (identifying characteristics of design thinking as opposed to traditional rational problem solving approaches prevalent in business settings). See also, generally, Jfannf LifDTkA R.T Al.., Solving; Probi.ems with Design Thinking: (20I3).
} 
Design thinking has been described as an "innovation process" used to discover unmet needs and create new product or service offerings. ${ }^{40}$ Design thinking can also transform businesses by solving complex and intertwined problems that are vaguely formulated, raise uncertain, sometimes conflicting, consequences, and implicate diverse decision makers. ${ }^{41}$ Many legal problems represent the same type of conflicting interests. The design of cybersecurity regulation, for example, deals with evolving technology and unknown threats while balancing the government's interest in access to information against important privacy concerns. Sometimes, the solutions are worse than the symptoms. ${ }^{42}$ The design thinking literature has identified methods and tools to address these problems, develop innovative solutions, and ultimately create value. ${ }^{43}$ The following discussion summarizes some of the basic elements identified in the literature to characterize the way designers approach problems, which serves as a basis for our Legal Design framework.

Design thinking often has been characterized as user centered, meaning that the needs of users are the driving forces behind the design process. $^{44}$ According to well-established design research, people tend to project their own thoughts and assumptions on others. ${ }^{45}$ To reach optimal product or service functionality, design thinking therefore emphasizes the importance of separating one's own rationales and beliefs from those of the user. ${ }^{46}$ To gain an understanding of both expressed and unexpressed user needs, the designer is supposed to see the world

\footnotetext{
${ }^{40}$ Thomas Lockwood, Design Thinking: Initgrating; Innovation, Customer Experience, and Brand Valt f xii (2009).

${ }^{41}$ See id. (describing design thinking as innovation process "adopted to help reinvent businesses, as in solving 'wicked' problems"). See also, generally, C. West Churchman, Wicked Problems, 14 Mgmi. Sci. 141 (1967).

${ }^{42}$ Churchman, supra note 41, at 141-42 (pointing out the importance of "taming" the entire wicked problem as opposed to partial solutions).
}

${ }^{43}$ See Steve Sato et al., Design Thinking to Make Organization Change and Development More Responsive, Design Mgimi. REv. June 2010 at 44, 46 (describing design thinking as "structured, yet responsive and flexible, approach to creating value").

${ }^{44}$ See Brown, supra note 34 , at 89.

${ }^{45}$ See Dunne \& Martin, supra note 34, at 519 (citing Donald A. Norman, Thr Design of Everyday Things (2002)).

4i Id. 
through the user's eyes and develop a certain degree of "empathy" without losing objectivity. ${ }^{47}$ The methods used for this initial phase in the design process are largely derived from ethnography. ${ }^{48}$ They include observation of the user in his or her natural setting, engaging with the user through interaction and interviews, and immersion through living the user's life. ${ }^{49}$

Following this phase of unstructured observation, the designer frames the user's needs by identifying patterns of the observed behavior and analyzing missing elements to develop a solution to a problem or innovate the process or product in question. ${ }^{50}$ Design thinking thus combines both analytical and synthetic elements. ${ }^{51}$ While legal or business reasoning typically uses deductive and inductive methods, ${ }^{52}$ design thinking is unique as it includes inductive, deductive, and abductive reasoning. ${ }^{53}$ Abduction or "retroduction" has been described as "reasoning that forms and evaluates hypotheses in order to make sense of puzzling

${ }^{47}$ See Glen et al., supra note 22, at 657 (citing Brown, supra note 34; Heather Fraser, The Practice of Breakthrough Strategies by Design, 28 J. Bus. Si RATEGY 66 (2007); Sabine Junginger, Learning to Design: Gizing Purpose to Heart, Hand, and Mind, 28 J. Bis. Sirtiegy 59 (2007)).

${ }^{48}$ See id. (describing the fundamental ethnographic principles underlying user observation); see also Sara L. Beckman \& Michael Barry, Innovation as a Learning Process: Embedding Design Thinking, 50 CAL. M(im T. REv. 25, 34-35 (2007) (explaining how ethnographic methods can be used to gather relevant information under time constraints).

${ }^{19}$ See Dunne \& Martin, supra note 34, at 519 (citing Dorothy Leonard \& Jeffrey F. Rayport,

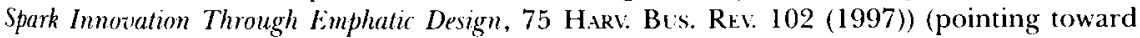
the importance of observation and interaction with the user as early as possible in the design process).

\footnotetext{
${ }^{50}$ See Beckman \& Barry, supra note 48, at 36 (examining a generic innovation process).

${ }^{51}$ See id. at 27 (citing Charles Owen, ITT INST. DrsIsis, Considering Design Fundamentally, Design Proci.ss Newsl., May 3, 1993, at 2).

${ }^{59}$ Colleen F. Johnson, Deductive Versus Inductive Reasoning: A Closer Look at Economics, 33 Soc. Sci. J. 287, 291 (1996) (citing Robfrt Martin. The. Philosopher's Dictionary 56 (1991)) (defining deduction as "reasoning from the general to the particular," and induction as "reasoning from the particular to the general").

${ }^{53}$ Dunne \& Martin, supra note 34 , at 518 (describing the interaction between deductive, inductive, and adaptive reasoning in design thinking and its benefits for business thinking); see also Johansson-Sköldberg et al., supra note 24, at 125 (citing Cross, supra note 11; Lalison, supra note 11).
} 
facts." ${ }^{54}$ In other words, it attempts to reveal possibilities and is therefore successful in dealing with complex innovations. ${ }^{55}$ Through the interaction of all three forms of reasoning, design thinking leads to the generation of new ideas but also validates them through analysis and evaluation. ${ }^{56}$

Interpersonal collaboration, and therefore mutual understanding, is key in the design process, not only to develop empathy for the user but also to facilitate peer collaboration. ${ }^{57}$ Collaboration helps to overcome personal bias, thereby enabling a full understanding of the user's needs. ${ }^{58}$ Working with people from different backgrounds broadens the perspectives of those entrusted with drafting regulation or forming a contract. ${ }^{59}$ The design literature argues that working with individuals who make one feel uncomfortable (so-called creative abrasion), is propitious to generating new ideas. ${ }^{60}$

The design process typically consists of the analytical phase of observation and understanding described above, followed by "synthetic

\footnotetext{
${ }^{54}$ Danielle D. Dunne \& Deborah Dougherty, Abductive Reasoning: How Innovators Natigate in the Labyrinth of Complex Product Innotation, 37 ORc: SrtD. 131, 135 (2016) (describing deductive reasoning and its analysis in organizational scholarship).

${ }^{55}$ See Karen Locke et al., Making Doubt Generative: Rethinking the Role of Doubt in the Research Process, 19 ORc. Sc:1. 907, 907 (2008) (distinguishing inductive, deductive, and abductive reasoning, and citing the initial proponent of the concept-Charles Sanders Peirce); see also Heather M. A. Fraser, Designing Business: New Models for Success, Desicin Mgmid. Rev: June 2009, at 56, 64 (stressing the importance of imagination and embracing radical new solutions).
}

${ }^{56}$ Dunne \& Martin, supra note 34 , at 518 (describing how a cycle of design thinking including all three ways of thinking generates new ideas).

${ }^{57}$ See id. at 519 (citing TOM KFIL.FY, ThF ART OF INNOVATION (2001)) (acknowledging that some designers might prefer to work alone but that even in these cases collaboration with users and peers is important).

${ }^{58}$ See supra note 45 and accompanying text; see also Kamil Michlewski, Uncovering Design Attitude: Inside the Culture of Designers, 29 ORG. STCD. 373, 378 (2008) (identifying "swinging between synthesizing and analy[z]ing" as one substantive category representing the professional culture of designers).

${ }^{59}$ See Dunne \& Martin, supra note 34, at 519 (stressing the importance of "expanding perspectives by collaborating with individuals unlike oneself").

${ }^{60} I d$. (citing Dorothy Leonard \& Susaan Straus, Putting Your Company's Whole Brain to Work, 75 Harv. Bus. Rev. 110 (1997)). 
phases of experimentation and invention." ${ }^{61}$ It moves between theoretical analysis and practical phases, where the designer creates graphic models or prototypes. ${ }^{62}$ These visualizations make ideas tangible. They facilitate both feedback from users and self-criticism, and they reveal inconsistencies language may not be able to detect. ${ }^{63}$ Exploration and iteration are important elements of the design process. ${ }^{64}$ Contrary to single-solution strategies, proposing multiple solutions to the client is an integral part of design thinking, as it allows for further clarification of the specific user needs. ${ }^{65}$

Initially practical or conceptual in nature, design thinking is now supported by empirical research showing how the methods and tools of design professionals can be applied more broadly to serve more general business and social purposes.$^{66}$ Nonetheless, using design thinking outside of its traditional boundaries has been discredited as little more than a marketing tool for design firms. ${ }^{67}$ The criticism is not primarily based

\footnotetext{
${ }^{61}$ Beckman \& Barry, supra note 48, at 27 (quoting Owen, supra note 51 ).

${ }^{69}$ See id.

${ }^{63}$ See Glen et al., supra note 22 , at 658 (describing the role of visualization and prototyping in the design process); see also Fraser, supra note 55, at 61 (describing the superior value of pictures and props over documents in this stage of the design process).

${ }^{64}$ See Glen, et al., supra note 22, at 658 (contrasting exploration with rational analytical problem solving methods); see also Michlewski, supra note 58, at 384 (observing that designers create "fundamental rahue through epistemologically unconfined exploration").
}

${ }^{65}$ See Glen et al., supra note 22, at 657 (contrasting scientific and design strategies to solve problems, and stating that designers' "solution-focused" strategies "may help clients further clarify... problem[s]").

${ }^{66}$ See generally, e.g., Roger Maki in, The Design of Business: Why Design Thinking Is the Nf.XI Competrine Advantage (2009); Brown \& Wyatt, supra note 10. In one particular example, a case study by Uehira and Kay describes how design thinking has been successfully used to improve patient experiences in Japanese hospitals. See generally Taisuke Uehira \& Carl Kay, Using Design Thinking to Improve Patient Experiences in Japanese Hospitals: A Case Siudy, $30 \mathrm{~J}$. Bus. Stratecry 6 (2009); see also Sean D. Carr et al., The Influence of Design Thinking in Business: Some Preliminary Observations, Desisin Mcimt. Rev. Sept. 2010, at 58. In their book, Solting Problems with Design Thinking, Jeanne Liedtka, Andrew King, and Kevin Bennett report on ten organizations' success stories in using design thinking in the management context. See Lifitro FT al., supra note 39. Design Kit's website contains many other practical examples. See Case Studies, Design Кп, http://www.designkit.org/case-studies (last visited May 2, 2016).

\footnotetext{
${ }^{67}$ See Peter Merholz, Why Design Thinking Won't Save You, 88 Harv. Bus. Rev. 18, 18 (2010) (arguing that design thinking is a "disingenuous term" because "[ $t$ ]he kind of interdisciplinary thinking we seek is not simply the purview of designers, and shouldn't be considered as such").
} 
on an inability of design thinking to address business or social concerns. Instead, the perceived shortcoming is its overemphasis on the professional designer's role, with a failure to link the designer theoretically with end users and other stakeholders in the design process. ${ }^{68}$ To spread the blame more broadly, however, the business field also has been criticized for not fully embracing design thinking, a failing attributable to an exaggerated reliability orientation and risk averseness. ${ }^{69}$ These shortcomings mask, however, a deeper divide between the methods used by designers, and those used by lawyers or business professionals, to solve problems. These challenges will be discussed in the next section, before we move on to the benefits design thinking offers in legal contexts.

\section{Challenges and Chances of Design Thinking in Legal Problem Solving}

The previous section shows that the way designers approach a problem or goal differs significantly from the analytical problem-solving approach that lawyers or business professionals would typically employ. ${ }^{70}$ The rational-analytical problem solving used by lawyers and business professionals assumes that all conditions, as well as the ultimate goal, are known. ${ }^{71}$ Designers frequently do not have a precise objective or definition of the problem they seek to address when they begin the design process; they experiment with various solutions, going through

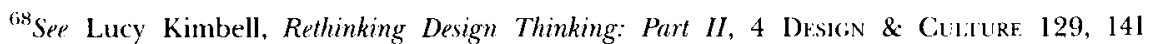
(2012) (describing how a "practice-orientation" allows the roles other stakeholders than the designer play in the design process to be taken into account).
}

${ }^{69}$ See Collins, supra note 37 , at 39 (identifying risk and failure aversion as reasons why business has not yet fully embraced design thinking); see also Kimbell, supra note 23, at 301 (citing Bruce Nussbaum, Design Thinking Is a Failed Experiment: So What's Next? Fast Сомрак Вія; (Apr. 5, 2011, 12:12 AM), http:/www.fastcodesign.com/1663558/designthinking-is-a-failed-experiment-so-whats-next)) (claiming, contrary to Nussbaum, that design thinking has not failed but needs to be studied more extensively and further theorized); see also Paul J.H. Schoemaker \& Robert E. Gunther, The Wisdom of Deliberate Mistakes, 84 HARv: Bis. Rev: 108, 110 (2006) (stating that "[m]any managers recognize the value of experimentation, but they usually design experiments to confirm their initial assumptions").

${ }^{70}$ See Glen et al., supra note 22, at 655-57 (contrasting design thinking and the rational problem-solving paradigm commonly used in business education).

${ }^{71}$ See id. at 657 (citing Bryan R. Lawson, Cognitive Strategies in Architectural Design, 22 ErcoNomics $59(1979))$. 
much iteration before issues are clarified and solutions are developed. ${ }^{72}$ In the beginning, they may have a broad goal or task, which they will further define. ${ }^{73}$ Objectives may even change over time as the understanding of the problem and its solution "coevolve." 74

A lawyer, in contrast, typically employs a more instrumental rationality. ${ }^{75}$ Before starting to work on a legal solution to a client's problem, the lawyer is likely to seek first a clear definition of the client's objective and gather as much information as possible to solve a client's case. Doing anything else runs counter to the professional duties a lawyer owes to the client. ${ }^{76}$ Spotting the legal issues in a case is the first and most crucial step in legal analysis. Overlooking a relevant issue will negatively impact the resolution of the case; becoming "distracted" by irrelevant issues will be unproductive and will likely result in an unclear and unconvincing argument. The "messy" working style of designers therefore seems to be at odds with the analytical skills in which lawyers are

\footnotetext{
${ }^{72}$ In this sense design illustrates the contrast between "management by objectives" and "management by discovery." The approach has been successfully used in project management where the success of the project was not defined by reaching the initial project objectives, but rather by how the goals were defined over the life of the project. See id. at 659 (citing Gary Klein \& Jay Rothman, New Directions: Staying on Course When Your Destination Keeps (hanging, 45 CONFERENCE. BOAR1) REv 24 (2008)) (observing how managers in an engineering project began their designs before completely defining the project objectives-a way of processing commonly associated with design thinking).

${ }^{73}$ See Kimbell, supra note 68, at 137 (describing the author's observation of designers trialing a smoking cessation service in a pharmacy).

${ }^{74}$ Glen et al., supra note 22, at 657; see also Richard J. Boland \& Fred Collopy, Design Matters for Management, in Manicinc: as Desicining: 3, 5 (Richard J. Boland \& Fred Collopy eds., 2004) (describing the authors' surprise observing a renowned designer tearing up his plans for a "perfectly good solution" he and others had worked on several hours and explaining his act with "[w]e proved we could do it, now we can think about how we want to do it").

${ }^{75}$ See generally Robert S. Summers, Pragmatic Instrumentalism in Twentieth Century Legal Thought-A Synthesis and Critique of Our Dominant General Theory About Law and Its Use, 66 Coknel.. L. REv: 861 (1981) (characterizing prevailing legal thought as instrumental rationality).

${ }^{76}$ See David Howarth, Law as Engineriking: Thinking About What Lawyers Do 74 (2013) (identifying specification of objectives as an important and common trait of transactional lawyers, legislative lawyers, and engineers).
} 
trained, and which are highly valued both within and outside the legal profession. ${ }^{77}$

However, legal work is not restricted to analytical problem solving. When counseling a client, a good lawyer is expected to find creative solutions. Exploratory techniques like "sketching" or "mapping" out different solutions, or even creating a "prototype" (e.g., a preliminary contractual document) are ways to test different solutions or potential scenarios. ${ }^{78}$ These are solution-based strategies typically used by designers, which not only help the expert to solve the problem more effectively, but also help clients better understand the solutions available to them. ${ }^{79}$

Legal analysis involves application of facts to legal rules, which takes place in a specific cultural environment and requires "perceiv[ing] connections between general standards and particular instances." 80 The application of facts to legal rules is not purely mechanical; it involves "a variety of inferences, deductions and connections ... to predict an appropriate resolution of the legal issue." 81 As one commentator states, "issue spotting provides a form of construction or creation." ${ }^{2}$ Legal education's focus on formulaic analysis therefore has been criticized as restricting students' creativity. ${ }^{8: 3}$ The question is how a lawyer's creativity can be strengthened without losing the benefits of the analytical skills for which they are praised and without relying on an individual lawyer's creative talent. The design-thinking literature

\footnotetext{
${ }^{77}$ See Michelle M. Harner, The Value of "Thinking Like a Lawyyer," 70 MD. L. Rev. 390, 391 (2011) (citing Eric Torbenson, Law Degrees Increasingly Aitractive for CEO Candidates, DallasNrws.com (Sept. 2, 2008, 7:22 AM), http://www.dallasnews.com/); see also Menachem Wecker, Where the Fortune 500 (EEOs Went to Law School, U.S. News \& Worl.d Rer. (June 26, 2012, 7:00 AM), http:/www.usnews.com/education/best-graduate-schools/top-law-schools/ articles/2012/06/26/where-the-fortune-500-ceos-went-to-law-school ("Of the 498 chief executive officers listed on the 2012 Fortune 500 list, 46 hold legal degrees.").
}

${ }^{7 x}$ On legal sketches see Mitchell, supra note 3. On legal maps, see McCloskey, supra note 5.

${ }^{79}$ See Glen et al., supra note 22, at 657 (stating that in the designer's way to approach "'wicked" problems... a great deal of thought and planning does not always precede action").

${ }^{80}$ Philip C. Kissam, Law School Examinations, 42 Vavo. L. Rfv. 433, 440 (1989).

${ }^{81}$ Kathleen Magone \& Steven I. Friedland, The Paradox of Creatize Legal Analysis: Venturing into the Wilderness, 79 U. Dei. Mercy I. Rev. 571, 574-75 (2002).

${ }^{82} I d$. at 574 .

${ }^{8: 3} I d$. (citing Andrew J. McClurg, Poetry in Commotion: Katko v. Briney and the Bards of FirstYear Torts, 74 OR. L. Rev. 823 (1995)) (criticizing the Socratic method for oppressing student's creativity). 
suggests that the dilemma between analytical thinking and creative problem solving could be addressed through abductive reasoning ${ }^{84}$ and is supported by dual process models of cognition. ${ }^{85}$

Psychological studies show that human reasoning uses two very different processes, referred to as systems. ${ }^{86}$ System 1 describes automatic cognitive processes; System 2 is more deliberate, "conscious reasoning." System 1 processes rely on "contextual, ... particularly visual cues" that are "intuitive" and "experimental." Human problem solving activities start with System 1 and some also end there. The more analytical System 2 serves to "decontextualize and depersonalize" the problem. System 2 thus represents the core of what legal analysis typically is about, serving as "a check on" System $1 .{ }^{87}$ Strengthening the creative processes in legal thinking could make legal thinking more innovative, while still controlled by the analytical processes in System 2. Combining legal thinking with aspects of design thinking thus produces unexpected benefits, and supplies the basis for our concept of Legal Design.

Legal Design is an evolution in the analysis of visualization intended to make legal communication easier, more user friendly, and more effective. It also strives to substantively improve the drafting process and the resulting public or private regulation. ${ }^{88}$ In turn, this positively transforms the significance and value of laws and traditionally word-heavy legal documents such as contracts or governance documents. ${ }^{89}$ In effecting these goals, the process by which visualization is created becomes as

\footnotetext{
${ }^{8.4}$ See supra note 54 and accompanying text.

${ }^{85}$ See Glen et al., supra note 22, at 659-60 (citing Steven A. Sloman, The Empirical Case for Tuo Systems of Reasoning, 119 Psychol. Bct.. 3 (1996); Keith E. Stanovich \& Richard F. West, Individual Differences in Reasoning: Implications for the Rationality Debate?, 23 BkH.w. \& BR.IIN Sci. 645 (2000))

${ }^{86-}$ The following description of dual process models largely builds on Glen et al., supra note 22 , at $659-60$.

${ }^{87}$ See id. See generally Daniel Kahnemann, A Perspective on Judgment and Choice: Mapping Bounded Rationality, 58 Aм. Psychorogiss 697 (2003); Stanovich \& West, supra note 85.

${ }^{88}$ See Berman, supra note 14, at 24.

${ }^{89}$ See Joh. Katz, Designing Information: Human Fictors and Common Sense in InformaIION DESIGN 10 (2012) ("Our job as designers is to design with intent, so that the objects we design function as they are supposed to for those who need them and use them.... Information needs to be in a form that [users] can understand and use meaningfully, and to tell the truth of what things mean and how they work.").
} 
important as the image itself. That process of design suggests the sort of inquiry and communication that has long been promoted by "Preventive Law" or "Proactive Law" (combined here as PPL). ${ }^{90}$

The methods and values of PPL reach back to the founding of the Preventive Law movement in the 1950s. ${ }^{91}$ The term "Proactive Law" emerged in the 1990s in Finland, and was quickly adopted in Europe, to stress positive goals and outcomes in legal transactions and to avoid problems. ${ }^{92}$ PPL distinguishes itself from traditional law and lawyering by its conscious orientation to the future rather than the past; its systems-oriented, contextual thinking rather than reductive analytical methods; its focus on the needs and relationships of those who use the law, as well as legal experts; its efforts to connect law with surrounding organizations and institutions; and its willingness to suggest interventions or restructuring of environments that generate problems or obstruct goals. ${ }^{93}$

From the PPL perspective, visualization becomes more actively and strategically planned. It becomes conscious "design," meaning both a noun - an image to advance communication-and a verb, the process by which text or spoken language is clarified by images that simplify and supplement language. This design process makes legal information intellectually accessible and functional. ${ }^{94}$ Where these goals are met, legal documents can become stronger generators of value rather than drivers of higher transaction costs. Contracts and other legal documents can facilitate better communication within and between organizations, and offer possibilities for innovation. ${ }^{95}$ It is against this background that we will develop a framework of Legal Design that effectively combines language and graphics to help organizations reach their preventive and proactive goals.

\footnotetext{
${ }^{90}$ See supra note 12 and accompanying text.

${ }^{91}$ See generally Locis M. Brown, Preveninve LaW (1950).

${ }^{92}$ See generally Berger-Walliser, The Past and Future of Proactive Law, supra note 12, at 13.

${ }^{99}$ See generally B.ARTON, supra note 12; Siedel \& Haapio, supra note 12.

${ }^{94}$ See generally User-Friendly Tools, supra note 12.

${ }^{95} \mathrm{On}$ the relationship between contract design and innovation, see Matthew $\mathrm{C}$. Jennejohn, Collaboration, Innovation, and Contract Design, 14 Stan. J.L. BL's. \& Fin. 83 (2008).
} 


\section{A Framework for Legal Design}

Our suggestions for Legal Design build on characteristics identified in the design thinking literature mentioned above.$^{96}$ Building on these criteria, we suggest methods and values for Legal Design as rooted in PPL.

Legal Design research is in its early stages, but proceeding quickly. A fully prescriptive theory - one expected to generate a single "right" procedure, image, or layout-may never be feasible, nor desirable. ${ }^{97}$ Fixed rules would be too restrictive to adapt to individual users' needs. More desirable is a creative, constantly innovative process that achieves a high "probability of correct use of a visualization, given information type and goal of the design." 98 That said, based on the design-thinking characteristics identified in Part I.B, we offer a framework for Legal Design below in the hope that it will spark greater awareness, more conscious use, and further exploration of the possibilities. Ultimately, through better process and conscious use of visualization, we hope to make legal communication more effective and user centered, thereby leading to conflict prevention and value creation.

The framework outlined below moves in graduated steps-from the most traditional and easily achieved by regulators and private drafters lacking design experience, toward those that are more strongly pictorial and may require more professional designer help. The steps are $(A)$ identify user needs through observation and empathy; (B) define project goals through communication, visualization, and prototyping; ( $\mathrm{C}$ ) communicate effectively through simplified language; (D) adapt to audiences with multiple needs through visual discourse; and (E) support legal functions through an optimal mix of language and graphics (see Figure 1). We discuss each step of the framework in the following sections.

The framework, like every design process, is iterative ${ }^{99}$ each step in the framework loops back into the previous one. Introducing a new

\footnotetext{
${ }^{96}$ See supra Part I.B.

${ }^{97}$ E-mail Correspondence with Stefania Passera, Master of Arts (Art and Design) and Doctoral Candidate, Department of Industrial Fngineering and Management, Aalto University School of Science, Finland (Oct. 10, 2015) (on file with the authors).

${ }^{98} I d$

${ }^{99}$ See supra note 61 and accompanying text.
} 


\section{E. 5upport legal} function through optimal mix of language and graphics

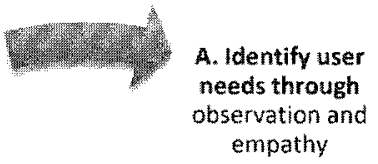

A. Identify user needs through empathy

\section{Adapt to \\ audiences with \\ multiple needs \\ through visual \\ discourse}

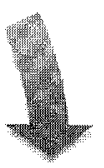

B. Define project goals through communication, visualization, and prototyping

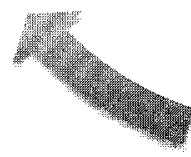

c. Communicate effectively through simplified language

FGURE 1. Framework for Iterative Legal Design. [Color figure can be viewed at wileyonlinelibrary. com]

design tool can generate new ideas or reveal a problem, which may in turn require going back to an earlier step to verify assumptions or address problems or new opportunities. ${ }^{100}$ Open-minded and flexible communication among the interested parties and legal drafter/designers-feedback loops-are important components of Legal Design and furthermore align with principles of PPL. ${ }^{101}$ Ultimately, the framework aspires toward goals expressed by PPL, such as dispute prevention, cost saving, and value creation, which guide every step in the framework.

The following sections explain the steps of the framework in greater detail.

\footnotetext{
${ }^{100}$ E-mail Correspondence with Stefania Passera, Master of Arts (Art and Design) and Doctoral Candidate, Department of Industrial Engineering and Management, Aalto University School of Science, Finland (Dec. 7, 2015) (on file with the authors).

${ }^{10}$ See Fraser supra note 55, at 58 (identifying collaboration and open-mindedness as essental for business design); see also Barton, sama note 12, at 57; Thomas D. Barton, ReDesigning Law and Laryering for the Information Age, 30 Notre Dame J.L ETHICs \& PuB. Pot'y 1 (2016).
} 


\section{A. Identify User Needs Through Observation and Empathy}

As stated earlier, design thinking is human or user centered. ${ }^{102}$ In other words, design thinking requires the designer to spend time with the client/user exploring collaboratively the function, or specific current or future use the client or other impacted person is likely (intentionally or not) to make of the work product. ${ }^{103}$ Transposed to the legal world, this means that the lawyer should take the user's needs into account when drafting a legal document and that the user should be involved in the drafting process. ${ }^{104}$ For legislative rulemaking this is an approach increasingly favored, for example, by the European Union. ${ }^{105}$ The European Commission's "Better Regulation Agenda" explicitly relies on stakeholder input and impact assessment at all stages of the life cycle of European regulation: from initial roadmaps and policy development over feedback on the Commission's proposals and draft delegated and implementing acts to review of existing legislation by subject matter experts from social partners, business, and civil society. ${ }^{106}$

On the business side, an increasing body of scholarship criticizes corporate legal practices that focus primarily on outcome and standardization $^{107}$ instead of user experience and product

\footnotetext{
10'-Brown, supra note 34, at 89; see also supra note 44 and accompanying text.

${ }^{103}$ See Boland et al., supra note 23 , at 15 (reporting on observations from a "Managing as Designing" workshop with designer Frank O. Gehry).

${ }^{104}$ See generally Gillian K. Hadfield, Equipping the Garage Guys in Lau, 70 MD. L. REv: 484 (2011) (describing an extracurricular case study session in which J.D. and M.B.A. students worked together to find a solution for a real company facing a genuine business challenge and showing the benefit of user involvement).

${ }^{105}$ See Opinion of the European Economic and Social Committee on 'The Proactive Law Approach: A Further Step Towards Better Regulation at EU Level,' 2009 O.J. (C 175) 27 , http://eur-lex.europa.eu/LexUriServ/LexUriServ.do?uri-

OJ:C:2009:175:0026:0033:EN:PDF (recommending "active and effective" stakeholder participation during the drafting and decision-making process).

${ }^{106}$ See generally European Comm'n, Better Regulation: Why and How, http://ec.europa.eu/ smart-regulation/index_en.htm (last visited May 5, 2016).

${ }^{107}$ George G. Triantis, Improving (ontract Quality: Modularity, Technology, and Innovation in Contract Design, 18 STaN. J.L. BL.s. \& Fis. 177, 179 (2013) (criticizing corporate legal practice for its focus on cutting costs through automation and standardization instead of developing better service).
} 
functionality. ${ }^{108}$ These studies imply that corporate lawyers and their clients tend to favor legal certainty and formal enforceability of contractual terms over efficiency-enhancing communication about business objectives and deliverables to the employees actually in charge of performing the contractual obligations. ${ }^{109}$ Applying design thinking to contract drafting yields a sharp contrast. Good contract design should identify the users' needs, communicate deliverables to the employees in charge of performing the contractual obligations, and serve the client's specific objectives, rather than assuming that contracts serve primarily as a defensive tool if litigation ensues. ${ }^{10}$ In line with PPL principles, the contract should address and solve business concerns and take into account the personal relationship between the contract partners. ${ }^{111}$

To do so, careful observation and understanding of the users' needs becomes a prerequisite for successful legal design and therefore builds the first step in our framework. In design projects, ethnographical methods are often used for observation. ${ }^{112}$ Although this might be an unusual practice for legal services, the benefit of counsel being intimately familiar with and understanding her client's business or personal situation has long been a central tenet of Proactive Law. ${ }^{113}$

In this sense, empathy with the user is another characteristic attitude of designers. ${ }^{14}$ However, empathy does not typically characterize lawyers, who have been educated to analyze a given fact scenario rationally

\footnotetext{
${ }^{108}$ See Mitchell, supra note 3, at 12 (suggesting that lawyers' focus on well-tested, standardized legal documents prevents them from being open to new ideas and taking into account their clients' real needs).

${ }^{109}$ See Triantis, supra note 107 , at 190 ("Efficiencies in the midstream of the contract lifecycle are often neglected by both lawyers and their clients."); see also Berger-Walliser et al., supra note 12, at 58 (suggesting that contracts should serve as roadmaps for performance).

${ }^{110}$ See Helena Haapio \& Thomas D. Barton, Business Friendly Contracting: How Simplification and Visualization Can Help Bring It to Practice, in Lieuid Legal: Transforming; Legal into a Businfss Savy; Information Enabled and Performance. Driven Indestry 364 (Kai Jacobs et al. eds., 2016).

${ }^{11}$ Thomas D. Barton, Improing Contracts Through Expanding Perspectives of Understanding, 52 CAl. W. L. Rev. 33, 36-41 (2015) (elaborating on the role of the personal relationship in contracting).

${ }^{112}$ See supra note 48 and accompanying text.

${ }^{113}$ See Barton, supra note 101, at 2.

${ }^{114}$ See supra note 47 and accompanying text.
} 
and exclusively apply legal rules to assess these facts. ${ }^{115}$ Usually a lawyer will ask a client about past actions or future goals and then determine reductively whether these activities comply with legal rules. Design thinking would lead the legal advisor to enter a constructive conversation to understand motivations and constraints, and-using abductive thinking-generate creative solutions to reach the client's immediate and long-term business goals. ${ }^{16}$ Though some lawyers achieve this already, the design-thinking literature and design practice provide a theoretical underpinning and practical tools to enhance creative communication between lawyers and their clients. ${ }^{117}$

Focusing on the human side of adding value to the future product, service, or experience, successful design firms have incorporated elements from anthropology, psychology, and sociology into their processes. ${ }^{118}$ To reach the intended results, they engage in visual discourse, visual thinking, creative dialogue, intuition, instinct, and tacit knowledge, concentrating on people and transparency of communication. ${ }^{119}$ Design practice provides methods such as value mapping ${ }^{120}$ or a needs pyramid ${ }^{121}$ to help with this process. If used in a legal setting, these tools could reveal

\footnotetext{
${ }^{115}$ Ser generally Lynne N. Henderson, Legality and Empalhy, 85 Mıci. L. Rev. 1574 (1987).

${ }^{116}$ See supra note 54 and accompanying text.

${ }^{117}$ The Legal Design Toolbox developed by the Legal Design Lab, an interdisciplinary team based at Stanford Iaw School and Stanford Design School provictes "a set of resources for aspiring designers who are approaching legal challenges with a creative, generative, human-centered approach." Legal Design Toolbox, Leciat. DESIG., LAB, http://www.legaltechdesign.com/LegalDesignToolbox/ (last visited May 5, 2016).
}

${ }^{118}$ Michlewski, supra note 58, at 383 (citing Tom Kelly, The Art of Innovation (2001); Susan Solires \& Bryan Byrne, Creating Breakthrolgh Infas: Thle Coltaboration of

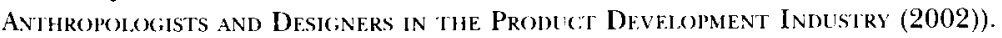

${ }^{119}$ See id. at 381-82 (identifying "engaging polysensorial aesthetics" as a prevalent design attitude); see also Glen et al., supra note 22, at 658 (distinguishing design thinking from rational analytical thinking).

${ }^{120}$ Value mapping consists of "document[ing] beliefs, preferences, priorities, frustrations, loves, hates, and other values..." [the designer] "can infer from what" [she has] "heard [and] observed." Legal Design Toolbox: Derelop a New Product or Service, Lecial. Design Lab, http://www.legaltechdesign.com/LegalDesignToolbox/develop-a-new-project/ (last visited May 5, 2016).

\footnotetext{
${ }^{121}$ A needs pyramid maps out user needs in the form of a pyramid moving from the less important to the most important need expressed by users in the observation stage of the design process. See id.
} 
motivations and concerns otherwise overlooked and potentially could inspire lawyers to provide a more user-centered service. ${ }^{122}$ Legal Design could be equally useful for business and for government-in a corporate setting for contract drafting or developing corporate policies, such as privacy rules or codes of conduct, or in a government setting for legislative drafting or creating public educational tools. ${ }^{123}$

\section{B. Define Project Goals Through Communication, Visualization, and Prototyping}

The observation phase leads to a phase in which project goals and restrictions are defined by means of communication, brainstorming, and prototyping. In this step, contradictions in expectations are identified, multidimensional meanings are consolidated, and new ideas are developed through reconciliation of contradictory objectives, bridging approaches, and abductive reasoning. ${ }^{124}$ Research analyzing designers' attitudes has described these individuals as able to "look at a situation from a wide variety of perspectives,' bringing together 'humanistic standpoint,' 'deep understanding' and technical limitations.... [T]heir strength lies in utilizing both [synthesis and analysis]_-putting things together' and 'taking them apart' simultaneously." ${ }^{25}$ This description of the designer's role arguably shifts the role of a lawyer from a legal service provider to a precontractual mediator or legal consultant, perhaps requiring new skills for some lawyers. ${ }^{126}$

\footnotetext{
122See introductory material developed by the Stanford Design School, STANFori UNIV'FrSI. IY IXSTITLTE of Desicix, http://dschool.stanford.edu/use-our-methods/ (last visited May 5 , 2016).

${ }^{12: 3}$ The Legal Design Lab's website offers various practical example for using design methods and tools for legal projects. See Our Design E Derelopment Projects, Lecisl. Drsisis LaB, http://www:legaltechdesign.com/our-projects/ (last visited May 5, 2016).

${ }^{124}$ See Michlewski, supra note 58, at 377-78 (describing design thinking as "swinging between synthesising and analy[z]ing").

${ }^{125} I d$.

${ }^{126}$ See Louis M. Brown \& Harold A. Brown, What Counspls the Counselor? The Code of Professional Responsibility's Ethical Considerations-A Presentive Lau Analysis, 10 VAl. L. Rev. 453, 454 (1976); see also, generally, Camilla Baasch Andersen, Pre-Contratual Mediation in Negotiation-Transplanting Techniques from Mediation and Introducing a Neutral Contract Facilitator, in Proactive LaW in a Business Environment, supra note 12, at 155 (introducing the idea of precontractual mediation in the contract negotiation stage).
} 
Shifting between analysis and synthesis requires the participating actors to keep an open mind and embrace discontinuity, characteristic of successful designers but atypical of lawyers who tend to be motivated by efficiency and legal certainty. ${ }^{127}$ To reach user-centered, innovative solutions, legal templates are likely to be too confining. Templates should be readily modified as a result of open-ended conversations. This requires all actors in the process to accept the iterative nature of the project, starting with initial brainstorming and then reaching from low-fi to high-fi prototypes. ${ }^{128}$ Though this step may significantly lengthen the drafting process, ultimately we expect it to prove valuable by facilitating implementation, avoiding misunderstandings, and preventing disputes. ${ }^{129}$ To help with this process, designers may use creative manifesting such as drawings, visuals, rapid prototyping, or other tangibles. ${ }^{130}$ Since both the preliminary and the final product of any legal design process is likely to be some kind of printed document (with or without visual representations), ${ }^{131}$ the remaining steps of the framework focus on how to enhance legal document design through effective choice of language and visuals.

\section{Communicate Effectively Through Simplified Language}

Legal Design can rarely dispense with words. Words constitute stateenforced rights and duties, and if a controversy arises, words must always be authoritative. ${ }^{132}$ That said, an indispensable step in Legal Design is for the drafters of the "legal language" to use words that are

\footnotetext{
${ }^{127}$ See supra note 79 and accompanying text; see also Michlewski, supra note 58 , at 380-81 (identifying and embracing openness and discontinuity as one of the characterizing attitudes found in successful designers).

${ }^{12 x}$ See Legal Design Toolbox: Detelop a Neu' Product or Service, supra note 120 (outlining the process to get from an idea to a finished product).

${ }^{129}$ See Barton, supra note 101 , at 12 (noting that attorney communication styles should be multidirectional with feedback loops).

${ }^{130}$ Michlewski, supra note 58, at 379 (reporting that the interviewed designers in the empirical research "share a real affection for creating things and bringing solutions to life").

${ }^{131}$ The final product need not be printed: students in one of the authors' MBA classes have suggested a three-dimensional model to represent contractual obligations.

${ }^{132}$ Barton, Berger-Walliser \& Haapio, supra note 2, at 48.
} 
as simple as possible to favor communication and attention to user needs. This step occurs either during the project development process described above or at the end of the Legal Design process when the final product-a legal document, contract, legislative draft, or educational material-is created. Our suggestions for this step of our framework are influenced by contributions of the Simplification Centre, based in the United Kingdom. The Centre suggests criteria for measuring good document design based on case studies and projects it has undertaken. ${ }^{133}$ Though Legal Design is not limited to document design, the criteria developed by the Simplification Centre are helpful in identifying methods and values for Legal Design. We recognize that some legal ideas are embedded in a specialized professional vocabulary that loses nuance if translated into everyday words. Wherever possible, however, legal jargon should be avoided. The Simplification Centre suggests the following criteria that may guide the current step of our framework-(i.e., simplified language): ${ }^{134}$ use direct language to assign responsibilities; use plain words to make the document easily understandable; use grammar and punctuation in conformity with the practice of good standard English; and make it easy for the reader to follow the argument of the text. ${ }^{135}$

Once the legal text is created pursuant to these criteria, the remaining steps of Legal Design are meant to supplement this formal language with graphics, not to supplant or modify the words of a negotiated contract or legislative directive. As stated in the Introduction, virtually all Legal Design will result in a hybrid between words and images; the text constitutes the formal law, but good layout and graphics can facilitate its easy access, understanding, and implementation. Scientific research suggests that visual thinking and language-based thinking actually overlap. ${ }^{136}$ The choice of the "visual and language modes of expression and

\footnotetext{
${ }^{133}$ See generally Rob Waller, What Makes a Good Document?: The Criteria We Use, Simpl.IfICATION CIR. (2011), http://www.simplificationcentre.org.uk/downloads/papers/SC2CriteriaGoodDoc_v2.pdf.

${ }^{134}$ Id. at 6-14 (identifying language criteria in order to "assess how easy it is for people to understand the words").

${ }^{135} I d$.

${ }^{136}$ See WARE, supra note 5, at 131 ("The existence of sign language clearly demolishes the idea that one mode is fundamentally visual and the other mode is fundamentally auditory.").
} 
the amount of each should depend on what is to be conveyed." ${ }^{137}$ For Legal Design to be effective, drafters need to choose carefully what type of information is conveyed in which form, and adapt it to multiple audiences. $^{138}$

The following two sections address these related concerns: first, how to adapt legal communication to different audiences beyond those who are legally trained; and second, how to express legal ideas to support the intended function of the law in a given context through an optimal mix of language and graphics. Following these steps certainly produces better products or images, but a thoughtful reflection on the functional quality of the images underscores the importance of design process that we are stressing in this article.

\section{Adapt to Audiences with Multiple Needs Through Visual Discourse}

A variety of tools can augment the understanding of even complex language, so that nonexperts may more readily use legal documents, and even experts may grasp complicated legal concepts more easily or faster. Visualization studies show that the most reliable methods for enhancing comprehension are "adjunct aids"-(i.e., visual organizers like structured text, boldface headings, internal summaries, outlines, matrices, tree diagrams, and tables). ${ }^{139}$ These tools allow users to develop a holistic understanding that words cannot convey. They make "thought and organi[z]ation processes visible ... [and] assist users in processing and restructuring ideas and information" without changing the content of the legal communication. ${ }^{140}$ "They clarify complex concepts into a simple meaningful display ... [and] promote recall and retention of learning through synthesis and analysis." ${ }^{141}$

\footnotetext{
${ }^{137} I d$. at 134 .

${ }^{138}$ See Mitchell, supra note 3, at 6 (reflecting on the lack of attention lawyers typically pay to the way in which they communicate: "For us, 'contract design' means substance, not its concrete expression").

${ }^{139}$ See Peter Robinson, Graphic and Symbolic Representations of Law: Lessons from CrossDisriplinary Research, 16 Мскоосн U. Electronic J.L. 53, 65-68 (2009) (summarizing existing studies on the effectiveness of "adjunct aids").

${ }^{1 \cdot 10}$ Id. at 66 (quoting Shumin Kang, Using Visual Organizers to Enhance EFL Instruction, 58 Exci. Langiare Teachivg; J. 58, 60 (2004)). For experimental verification of the enhanced usefulness of well-designed documents, see User-Friendly Tools, supra note 12.

${ }^{141}$ Robinson, supra note 139 , at 60 .
} 
Some of these tools are relatively easy to implement even by lawyers and regulators without any prior design training or practice; others may require more talent or professional designers' help. But with the advancement of graphic software, even slightly more sophisticated visuals, such as diagrams, become readily accessible to almost everyone and can enhance understanding for legally trained as well as untrained audiences.

A somewhat more sophisticated processing tool, which not only improves readability but also allows adaption to multiple user needs, is "layering." As the term suggests, layering creates alternative layers of information that vary in depth or style. Layering responds to differing needs of different users, such as legal experts, who are concerned about different issues in a legal document than the subject-matter experts who are in charge of its implementation. Layering can also address the needs of just one user at different times when either careful study of particulars may be needed, or instead a simple reminder of general points. It also can express information in different formats-for example, graphic images, words, sounds, and shapes-that appeal to different learning styles or that accommodate users with disabilities. ${ }^{142}$

In its basic form, layering can be achieved using different levels of particularity. Authoritative text can be accompanied by additional levels of abstraction to make text navigation and information retention easier. For example, keywords (at a higher level of abstraction) or definitions (at a lower level of abstraction) can be moved out of the main text to become notes in a column next to the body of the text. ${ }^{143}$

Layering can also be used to present information by breaking down a larger whole into discrete, more easily digestible parts. Some of these layers are visual, fast, and easy to understand, while others are more complicated, text heavy, and require deeper analytical analysis. The user typically starts to absorb the information with the first, intuitive layer, followed by more analytical processes in the following layers. Such segmentation advances clear thinking and the possibility of finding

\footnotetext{
${ }^{142}$ See Brunschwig, supra note 3, at 263, 256-60 (describing efforts to use multisensory virtual reality software and brain-computer interface in legal communication among persons with various disabilities).

${ }^{14.3}$ For practical examples, see Rob Waller, Layout for Legislation, SimplificA11ON CTR. 13-16 (2015), http://www.simplificationcentre.org.uk/downloads/papers/SC15LayoutLegislationv2.pdf.
} 
more particularized solutions to problems through combining different permutations of the analytical layers.

The licensing images used by the sharing website "Creative Commons" ${ }^{144}$ combine analytical layering with a user-operated algorithm of choices, which result in solutions that are tailored to a problem holder's particular needs. Creative Commons is a nonprofit organization that provides standardized copyright licenses to enable people to easily share and use their creative works and knowledge through free legal tools on its website. ${ }^{145}$ Creative Commons' licenses rely on three layers of information, and users can click on recognizable icons to reveal the different versions. ${ }^{146}$ As illustrated in Figure 2, these permutations are the so-called Legal Code (the "lawyer readable" version-the full license), the Commons Deed (the "human readable" version), and the "machine readable" version of the license. ${ }^{147}$

To choose a license, a creator of a work who wishes to become a Creative Commons licensor answers a few simple, direct questions, such as "Do I want to allow commercial use?" and "Do I want to allow derivative works?" The introductory text to the Creative Commons licenses invites the reader to think of the Commons Deed "as a user-friendly interface to the Legal Code beneath."148

\footnotetext{
${ }^{144}$ Creative Commons, http://creativecommons.org (last visited May 5, 2016).

${ }^{1+5}$ See What We Do: What Is Creative Commons?, Creatrve Commons, http://creativecommons. org/about (last visited May 5, 2016).

${ }^{146}$ See About the Licenses: What Our Licenses Do, Creative Commons, http://creativecommons. org/licenses (last visited May 5, 2016).

${ }^{147} I d$. ("Taken together, these three layers of licenses ensure that the spectrum of rights isn't just a legal concept. It's something that the creators of works can understand, their users can understand, and even the Web itself can understand.").

${ }^{148} I d$.
} 


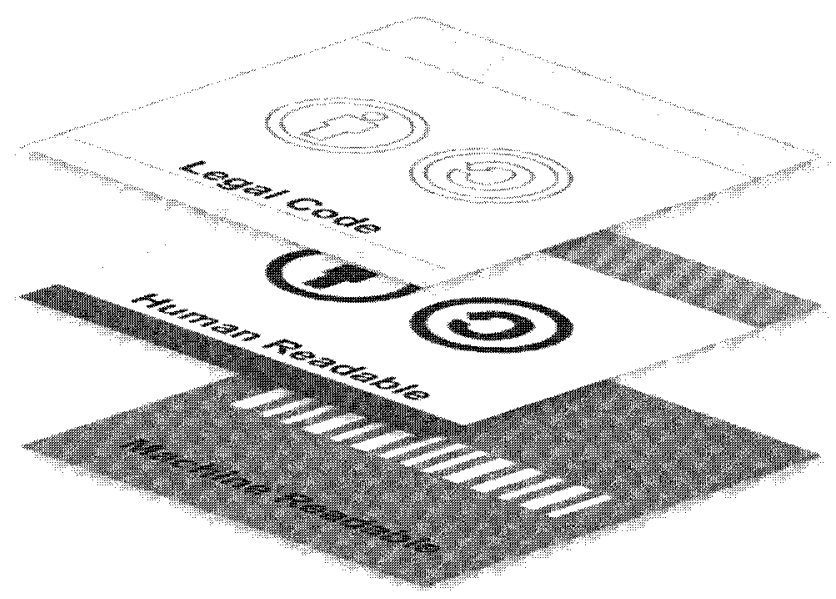

FIGURE 2. The Thre Layers of Creative Commons Licenses. " [Color figure can be viewed at wileyonlinelibray,com]

Other projects have proven how credit card agreements, consumer contracts, and commercial contracts can benefit from a more userfriendly approach. ${ }^{150}$ The U.K.'s National Archive is developing "new online formats for legislation, which would not only link explanatory notes to legislation, but which would also highlight those parts of an Act

\footnotetext{
${ }^{149} \mathrm{Id}$. (Image released under a Creative Commons Atribution 4.0 International license (CC BY 4.0)). For a "human-readable" summary of the so-called Legal Code (the full license), see Athibation t.o Intemational, CREATrve Commons, https:/creativecommonsorg licensesby/4.0/ (last visited May 5, 2016).

${ }^{150}$ See Know Before You Owe, Consumer Fin. Protechon Buread, htpd/www.consumerf nance gov/credit-cards/knowbeforeyouowe (last visited May 5, 2016); see also Multidisciplinary Project, Ptain-Language Writers, Designers, Usability Experts and Lawyers Put Their Heads Together, 65 Clakry 24, 26-27 (2011), http//www.darity-international net/joumals/ 65 darityjoumal pdf (reporting on the simplification of Gautrain's liability disclaimer). For commercial contracts, see Helena Hahio, Next Generation Contructs: A Paradigm Shmt (2013); Helena Haapio, Good Contrats: Bringing Design Thinking into Comtract Design, in Pkocendras of the 2013 IACCM ACademic Forum for Integratrg Law and Contract Man-

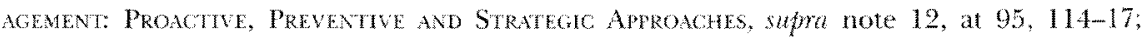
Stefania Passera \& Helena Haapio. Transforming Contrats from Legal Rules to User-Centered Communication Tools: A Human-Infomation Interacton Challenge, 1 Comy. Desion Q. 38 (2013), http:/sigdocacm.org/wp-content/uploads/2012/09/CDQ-Apri-1-3-FINAL pdf.
} 
which had been amended or were not currently in force." 151 These examples also rely on layered information, often combined with simplified language, to advance both analysis and problem solving.

Other helpful devices to make information more accessible to multiple audiences include diagrams ${ }^{152}$ such as swim lanes ${ }^{153}$ and timelines. ${ }^{154}$ Those responsible for negotiating and executing contractual agreements in organizations, such as subject-matter experts or engineers, are often more accustomed to "reading" a flowchart than text. Graphic tools adapt legal documents to the expectations of these audiences. They can help to allocate responsibility among multiple parties, demonstrate sequence, and highlight systemic relationships, as well as serve as easily accessed reminders of periodic deadlines.

Drafters can use swim lanes, tables, or matrices to create order and structure among logical categories. ${ }^{155}$ Figure 3 depicts a clause in a standardized public procurement contract. The colored swim lanes used in the figure illustrate the parties' obligations regarding the monitoring of service quality. They clarify who has to do what, where customer and supplier need to collaborate, and when additional obligations occur. Obligations which require immediate action from one of the parties are highlighted by a "to do" sign.

Flowcharts or timelines are suitable to illustrate dynamic processes, or the evolution of different contingencies. Flowcharts can be used to define the different paths a certain process may follow (e.g., a flexible

\footnotetext{
${ }^{151}$ Waller, supra note 143, at 17 (citing Carol Tullo, Re-Imagining Legislation and Official Publications-By Design?, http:/www.simplificationcentre.org.uk/events/clearer-legal-information/ (last visited Feb. 3, 2017)).

${ }^{152}$ Diagrams or graphs are symbolic representations of information using some visualization techniques.

${ }^{153}$ Swim lanes are often used in process flow diagrams or flowcharts that illustrate roles and responsibilities for different parts of a process. The swim lanes may be named, for example, Customer and Supplier, or Sales, Finance, and Legal, with one lane for each party or function. Ser, e.g., infra Figure 3.

${ }^{154}$ Timelines are diagrams that display events in chronological order.

${ }^{155} \mathrm{E}$-mail Correspondence with Stefania Passera, Master of Arts (Art and Design) and Doctoral Candidate, Department of Industrial Engineering and Management, Aalto University School of Science, Finland (Oct. 10, 2015) (on file with the authors)
} 


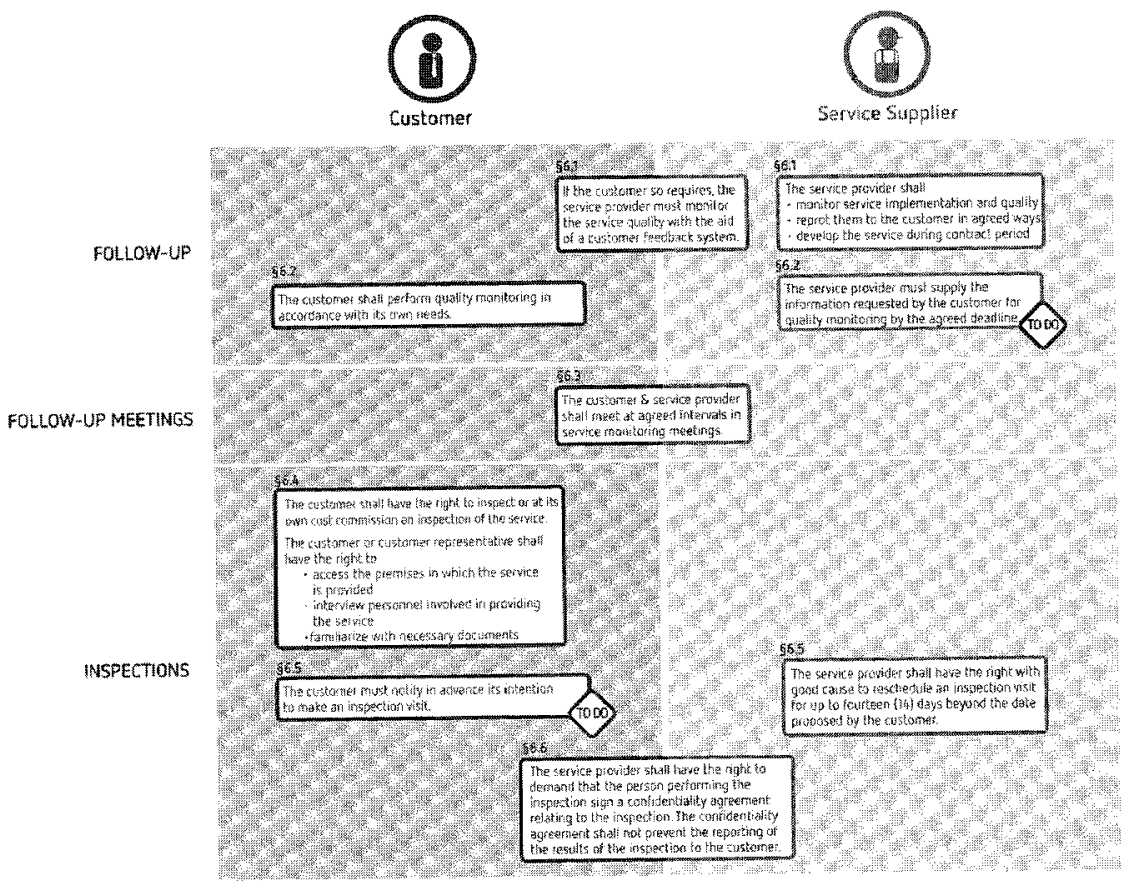

FIGURE 3. Swim Lanes Depicting Parties Obligations in a Public Procurement Contract. 02013 Aalto Universiry/Kuntalitto ry. Design: Stefana Passera. Used with permission. ${ }^{156}$ [Color figure can be viewed at wileyonlinelibrary.com]

price or the procedure to follow in case the customer suggests a price change, as illustrated in Figure 4). A timeline, on the other hand, can be used to clearly identify timespans, durations, deadlines, or milestones. $^{157}$

The design methods and examples presented above can make legal communication faster and more effective, and can help to avoid

${ }^{156}$ Crer-Friondly Tools, supra note 12.

${ }^{157} 7 \mathrm{~d}$ 


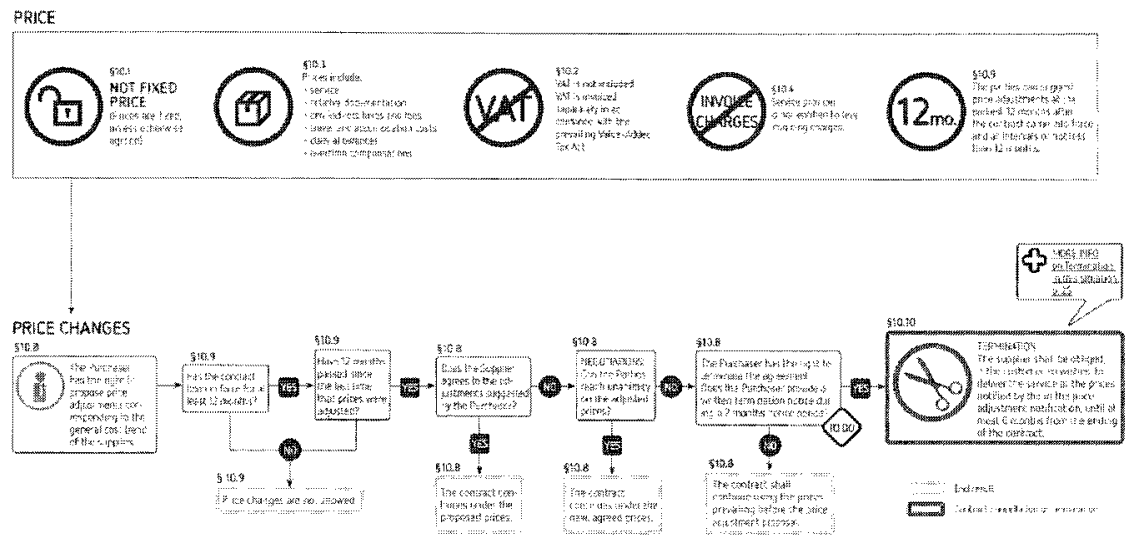

FIGURE 4. Flowchart Depicting Price Changes and the Customer Suggesting a Price Change in a Public Procurement Contract. 02013 Aalto Univeristy/Kuntalitto ry. Design: Stefania Passera. Used wh permission. ${ }^{158}$ [Color figure can be viewed at wileyonlinelibrarycom]

misunderstandings. ${ }^{159}$ Their purpose is to adapt contracts, other legal documents, and regulations to the needs of their users, to augment understanding, and enhance user experience. However, these are not the only functions of legal transactions in a given context. Particular designs should support the intended functions of the law. To achieve some legal functions, stronger use of graphics and fewer words may be suggested. For other legal purposes, words will predominate. This observation leads to the next step of the framework-supporting legal functions through the optimal mix of language and graphics. In the following section we distinguish different functions of the law. We then analyze the combination of words and images that best supports these functions and integrates them in the design process.

\section{E. Support Legal Function Through Optimal Mix of Language and Graphics}

The "process" qualities of Legal Design are emphasized in the fifth step-finding the optimal mix of language and graphics to support particular legal functions for particular contexts. Different contexts require

\footnotetext{
${ }^{158} I d$.

${ }^{159}$ See Helena Haapio et al., Time for a Visual Thtm in Contrating?, J. Contraca Momr: 49, 54-55 (2012) (providing an example of how a timeline potentially could have prevented a $\$ 2$ million lawsuit over the meaning of a contract termination clause).
} 


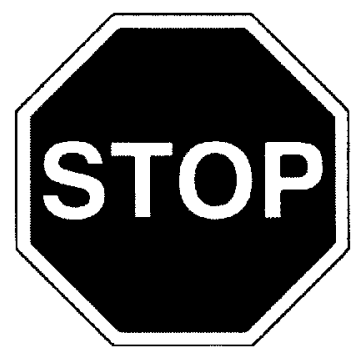

FIGURE 5. Stop Sign. ${ }^{\text {i60 }}$ [Color figure can be viewed at wileyonlinelibrary.com]

legal information to be expressed and communicated quite differentlyif it is to be effective in each context.

Occasionally, for example, the compelling function of the law is to secure social order through unthinking obedience to the law's commands. This may not happen often, but in some contexts quick and consistent compliance is needed. A graphic, accompanied by the simplest text in the form of a command, may be the most effective method. The humble stop sign (Figure 5) uses a legal visualization that achieves a high level of legal functionality with elegant simplicity. Stop signs illustrate that when the visual coding of a legal norm is well designed for one or more functions that the law must play, the visualization can be an indispensable accompaniment to the legal rule itself. ${ }^{161}$

Stop signs illustrate a strong strategic goal on the part of the creator of the image-here, municipal officials who need to regulate traffic at road intersections. For stop signs to function well-that is, for the legal

\footnotetext{
${ }^{160}$ Vienna Convention Road Sign, Wıimfina Commons, https://upload.wikimedia.org/wikipedia/commons/l/le/Vienna_Convention_road_sign_B2a.svg (last visited May 5, 2016).

${ }^{161}$ Michal Dudek, Why Are Words Not Enough? Or a Feu Remarks on Traffic Signs, in Proburms of Normativiti, Rulifs, and Rlit-Following, 363, 366 (Michał Araszkiewicz et al. eds., 2014) ("[T]raffic signs. . can be regarded as an integral, not secondary part of certain legal provisions and legal norms encoded by these [background regulatory] provisions. [The e]xample of traffic signs clearly shows that, although the statutes and regulations are thought of in terms of specific linguistic expressions their strictly visual dimension should also be taken into account."); see also Brunschwig, supra note 3, at 245.
} 
goal to be well met-the graphic image that embodies the law must induce quick, unreflective, and unswerving obedience by the "user" (i.e., the automobile driver who encounters the stop sign). The stop sign simply visualizes a nonnegotiable legal command ("Stop!") with a standardized octagon shape and red color surrounding a single word. Though simple, the visualization of this traffic regulation strongly advances the vital function of the underlying law-to prevent collisions. Similarly, in a contractual setting, the swim lanes in Figure 3 are completed by a "to do" sign in the shape of a traffic warning sign, which suggests to the observer that immediate attention is required.

Sometimes, in contrast, visualization is intended to deepen understanding of the law. The goal is to help people understand legal language conceptually. In these instances, "obedience" is not the intended goal; instead, "structural comprehension" might be a better description of the intended function of the law and its accompanying image. To be successful in aiding the law in this different way, the design of the image must be quite different. Visual metaphors ${ }^{162}$ and icons have been

\footnotetext{
${ }^{162}$ A metaphor functions almost conversely to the stop sign visualization. Rather than conveying an immediate and simple message to obey, a metaphor may invite unhurried reflection by the viewer as the viewer mentally imagines more and deeper connections between the image and the idea conveyed, aided by conversations that supply words to accompany the images. Mccloskey describes, for example, the "fruit and tree" metaphor that can help explain tax concepts and property law's commonplace "bundle of sticks" metaphor. See McCloskey, supra note 5, at 166-67. Metaphors, however, are not always helpful; they may be too powerful or too weak. Metaphors that are too powerful confine imagination too strongly into channels that are difficult to break. The ubiquitous "pie" metaphor, for example, can too strongly suggest that a problem can be resolved only through zero-sum outcomes that slice up resources for distribution among contending parties. Creative ideas for expanding the pie, thus benefitting everyone, are not intuitive to the image. A completely different difficulty with using metaphors is the need for the user to make quick connections between the image and the concepts when that ability is dependent on what the user already knows. As the authors discovered, those connections depend on cultural exposure to past uses of the metaphor. Although the "bundles of sticks" and "fruit and tree" metaphors resonate easily with U.S.-trained lawyers, those same metaphors are not part of continental legal training. They were meaningless, even confusing, when presented to one continentally trained author of this article. Hence, reference to an image or metaphor may be highly suggestive to one person but not to another.
} 
suggested to help users make more thoughtful, better-informed decisions. ${ }^{163}$ As a way to better understand the law, they will be most useful in educational settings, in pretransactional lawyer-client communication, or in communications between government and citizens, where stronger understanding of the regulation-for example, the tax code-could lead to improved compliance with the law. ${ }^{164}$

A different way of achieving a "structured comprehension" of the law is by structuring thought through icons or other symbols that have little or common cultural relativity. Tobias Mahler, for example, seeks ways of graphically interfacing the laws with their users that are more "logically" than "design" oriented. ${ }^{165}$ Using the shapes and symbols of traffic signs as a foundation, Mahler builds a visual vocabulary of the "deontic logic" of the law. ${ }^{166}$ Examples of what he terms the various "normative modalities" of the law ${ }^{167}$ are portrayed in Figure 6: "obligation" (a duty); "permission" (but not required); "prohibition" (forbidden); and "no obligation" (an exception to a duty-permission not to do something that ordinarily is required). ${ }^{168}$

\footnotetext{
${ }^{163}$ See id. at 164-65 ("A legal map is a mediation device between the law and a client's needs to make a decision, a tool to be used by lawyers acting as legal guides. As travelers use maps of a physical landscape to decide the best way to go, lawyers create and use maps of the legal landscape to counsel clients on the best way to go."); see also Meyers, supra note 5, at 398 (explaining that imagery can be used to strengthen retention of legal concepts).

${ }^{16.7}$ On prior efforts to make IRS forms and other regulations easier to understand through use of plain English, see Caitlin Legacki, Plain Language Bill Passes the Senate!, PlandancivaGE.Gor (Sept. 28, 2010), http://www.plainlanguage.gov/news/braleyBillPasses.cfm. See also, generally, Annetta Cheek, The Plain Regulations Act, HR 3786, 91 Мıсн. B. J. 40 (May 2012) (addressing some criticism of the Plain Regulations Act).
}

${ }^{165}$ See Mahler, supra note 3 , at 311.

${ }^{166} I d$. at 316. As Mahler explains,

If we want to create a graphical user interface for legal texts, we ideally need a stable basis for designing a graphical representation that can be used and understood by anyone in the world, regardless of jurisdictional or cultural background. Arguably, a simplified account of legal logic presents an adequate starting point for graphical modeling of legal norms.

Id. at 315 .

${ }^{167} I d$. at 317 .

${ }^{168} I d$. at $316-17$. 


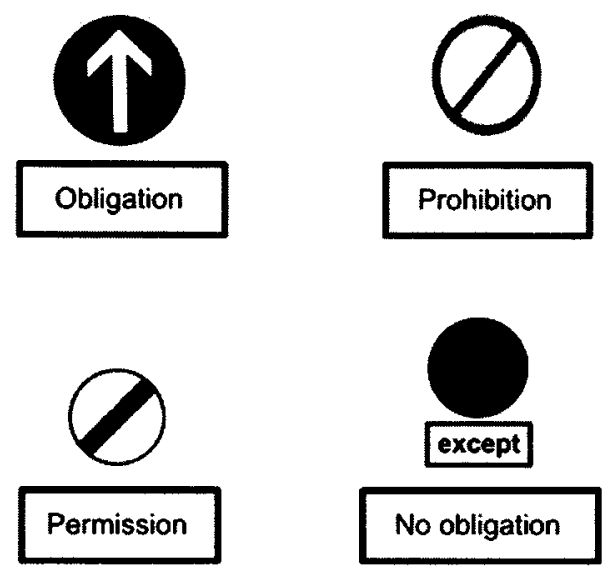

FIGURE 6. Visualization of Simplified Deontic Square. ${ }^{169}$ [Color figure can be viewed at wileyonlinelibrary.com]

The use of such icons could enhance user understanding and effectiveness. They may "highlight certain aspects of a legal text," ${ }^{70}$ signaling the reader where the words constitute a prohibition or a duty. That in turn "may be a good guidance for future conduct, and visualization could contribute to an initial level of understanding." 171

Another suggestion to enhance a reader's understanding of legal texts through a more formal system of design is combining standardized usage of lines, shapes, arrows, colors, and the thickness or thinness of lines into diagrams that express more complex legal rules. ${ }^{172}$ Standardizing symbols or icons could have more significant consequences; once digitized and made available in user-friendly software, individual users may be able to create visualized contracts or other image-enhanced documents for themselves.

[I]n the future it might even be feasible and useful to create a legal text using a graphical user interface. For example, when drafting a contract, the

${ }^{169} I d$. at 317 .

${ }^{170} I d$. at 323 .

${ }^{171} I d$.

${ }^{172}$ See Conboy, supra note 11, at 91-93 (suggesting the standardization of diagrams through ten usage rules that would eventually ease de-coding and make diagrams more consistent). 
parties might drag icons onto a diagram, thus creating an obligation or a prohibition based on pre-existing text templates of relevance to the contractual context. ${ }^{173}$

Alternatively, perhaps avatars could guide the general public using egovernment services. ${ }^{174}$ It may even become possible to generate such images automatically. If legal texts and images reach a level of standardization that they can be computer-generated and subjected to automated searches and analysis, then initially higher coding costs will be reduced even further, and accompanied by significantly lower transmission, retrieval, and de-coding costs. ${ }^{175}$ If attractive and easy to use, these

\begin{abstract}
${ }^{173}$ Mahler, supra note 3 , at 324 . On the prospects for computerized generation and analysis of visualized contracts, see, for example, Stefania Passera et al., Making the Meaning of Contracts Visible-Aulomaling Contract Visualization, in Transparency: Procendongs of The 17. Th

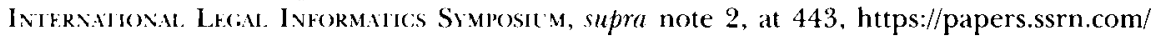
sol3/papers.cfmabstract_id $=2630609$ (combining information design, user experience, readability, visualization and natural language processing); Meng Weng Wong et al., Computational Contrart Collaboration and Construction, in Co-Operition: Procefondes of the 18Th

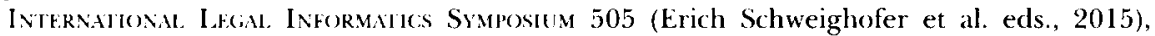
https://papers.ssrn.com/sol3/papers.cfm?abstract_id=2613869 (analyzing a four-part framework of automation, visualization, collaboration, and formalization in an effort to merge computing with "do-it-yourself" law, and envisioning an automated contract generation toolkit which expands term sheets into long forms); Primavera de Filippi, Legal Framework for Crypto-Ledger Transactions, P2P Fol ND. Wiki (Feb. 28, 2015, 2:16 PM), http://p2pfoundation.net/Legal_Framework_For_Crypto-Ledger_Transactions (discussing the prospect for "smart" contracts). The idea of "smart contracts" that can evaluate themselves for compliance and trigger business events was presented by Nick Szabo more than twenty years ago. See Michael Gord, Smant Contracts Described by Nick Szabo 20 Years Ago Nou Becoming Reality, Brrc(os M.s. (Apr. 26, 2016), https:/bitcoinmagazine.com/articles/smart-contractsdescribed-by-nick-szabo-years-ago-now-becoming-reality-1461693751.Later research has developed these ideas further. See, e.g., Harry Surden, Computable Contracts, 46 U.C. Davis L. Rex: 629 (2012) (describing computable contracts and their relevance to computerized finance, with an emphasis on machine-readable data elements); Mark D. Flood \& Oliver R. Goodenough, Contract as Automaton: The Computational Representation of Finamcial Agreements (Office of Fin. Research, Working Paper No. 15-04, 2015), http://ssrn.com/ abstract $=2648460$.
\end{abstract}

${ }^{17+}$ See Dimitros Rigas \& Badr Almutairi, Using Multimodality and Expressive Atratars in e-

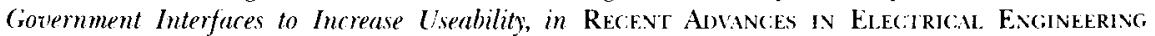
and Entchional. Technologits 33, 34 (Cornelia Aida Bulucea et al. eds., 2014). The Rigas and Almutairi paper "examine[s] the role of... facially-expressive and full-body avatars in e-government interfaces.... The effect of multimodal metaphors... [is] to increase user trust." Id. at 33.

${ }^{175}$ Mahler, supra note 3 , at 323 . ("An initial objection may be that this would imply a considerable degree of additional work for the person adding the visuali[z]ation to the text. In this respect, it is worth noting that it is possible to extract normative modalities 
digital tools could potentially better engage expert and nonexpert users; thus, automating the generation of text and visuals could be democratizing rather than dehumanizing. ${ }^{176}$ But even if the images become machine generated, someone must write the programming that pairs particular images with particular needs. How should those decisions be guided? What images should be generated for which circumstances? The choice of effective, efficient, and attractive images to support the intended legal function is illustrated in the following case studies, together with the process leading up to their creation.

\section{Illustrative Case Studies}

The framework offered above can work as a prospective process guide for Legal Design. In this section, we offer two case studies of successful Legal Design-one in the regulatory/public sphere (public regulation) and one in the private sector (trademark licensing). Both case studies are consistent with general principles of PPL ${ }^{177}$ and together demonstrate the steps of the design framework: observation of client environment and needs; clear process goals; effective communication through simplified language and images; strong adaptation to particular, multiple user needs; and resulting support for the legal function. Together, the case studies reveal how design characteristics, such as communication and collaboration, as well as systemic thinking, overlap with general principles of PPL. ${ }^{178}$

The Street Vendor Project of the Center for Urban Pedagogy (CUP) particularly illustrates the possibilities for good design that emerge from

automatically from a text. A possible approach to automation could use text parsers or soltware for syntactic text analysis to select sequences of text in legal sources. This automatic analysis yields a normative modality, which could then be visually annotated. Thus, by combining two approaches, automatic text analysis and this article's initial graphical language, it might be possible to create a completely new functionality.").

${ }^{176}$ See Michael Curtotti et al., Interdisciplinary Cooperation in Legal Design and Communication,

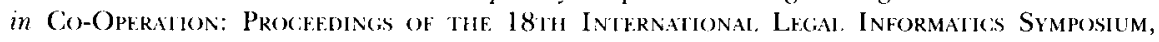
supra note 178 , at $45.5,458-60$, http://ssin.com/abstract $=2630953$ (contrasting the democratizing function of legal design to a "command theory of the law"); see also Sherwin et al., supra note 1, at 267-68.

${ }^{177}$ See supra notes $90-96$ and accompanying text.

${ }^{178}$ See id. 
strong observation and empathy for the user; effective communication; and adaptation to multiple, diverse audiences. The project began with an advocacy group for the thousands of merchants who sell their wares on New York City sidewalks. ${ }^{179}$ The group was founded in 2001 by Sean Basinski, a lawyer and former vendor: ${ }^{180}$ Basinski noted that the elaborate New York City Code regulating the vendors was intimidating and hard to understand by anyone, let alone someone whose first language is not English. ${ }^{181}$ To protect street vendors from unwittingly falling afoul of the law-with sometimes devastating consequences of $\$ 1,000$ fines-the Project collaborated with the CUP ${ }^{182}$ and Candy Chang, a designer, urban planner, and artist. The goal was to produce a visual Street Vendor Guide called Vendor Power! that "decodes the rules and regulations for New York's 10,000 street vendors so they can understand their rights, avoid fines, and earn an honest living." 18.3 Figure 7 illustrates the difference between text ("Before") and visual guidance ("After").

How did the Guide unfold? It began with first-hand knowledge and empathy for the plight of the intended user-the street vendors themselves. As Candy Chang describes,

While meeting at Sean's office to learn more about vending issues and challenges, he pulled out a box containing heaps of pink tickets they've accumulated from local vendors: The violations are mostly for the physical position of vendors' carts and tables, which must be certain distances from curbs, crosswalks, and building doors. Vendors are also frequently ticketed for not "conspicuously" wearing their vending license and for setting up shop on

\footnotetext{
${ }^{179}$ See Candy Chang, Making Policy Public: Vendor Pouter!, Urb. Omnısus (May 6, 2009) http://urbanomnibus.net/2009/05/making-policy-public-vendor-power/.

${ }^{180} I d$.

${ }^{181} I d$.

${ }^{182}$ The Center for Urban Pedagogy served as project manager and provided working stipends, research assistance, and direction throughout the process. Id.

${ }^{183}$ See Vendor Power!, CTR. URb. Pedaciogr, http://welcometocup.org/Store?product_id=17 (last visited Mar. 21, 2016); see also Candy Chang, Street Vendor Guide, Candy Chavi, http:// candychang.com/main/street-vendor-guide/ (last visited Nov. 1, 2016).
} 


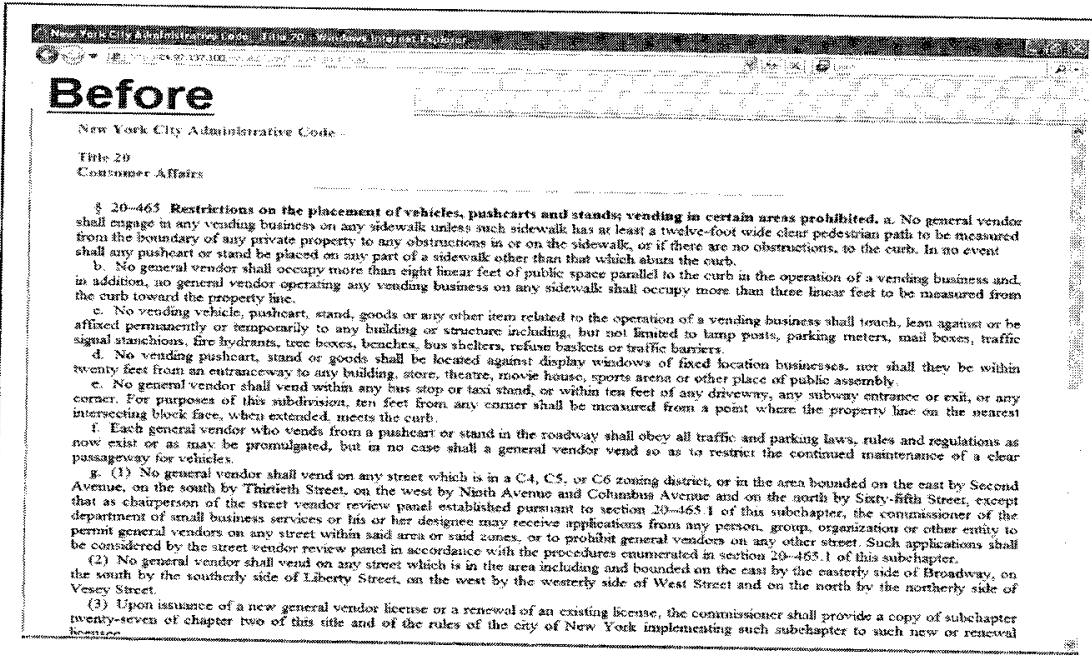

\section{After}

\section{Excerpt from Vendor \\ Powert - a visual guide to the rights and duties for street vendors in New York City, created by a collaboration of the Center for Urban Pedagogy, Candy Chang. and the Stree? Vendor Project. (c) 2009 The Center for} Urban Pedagogy

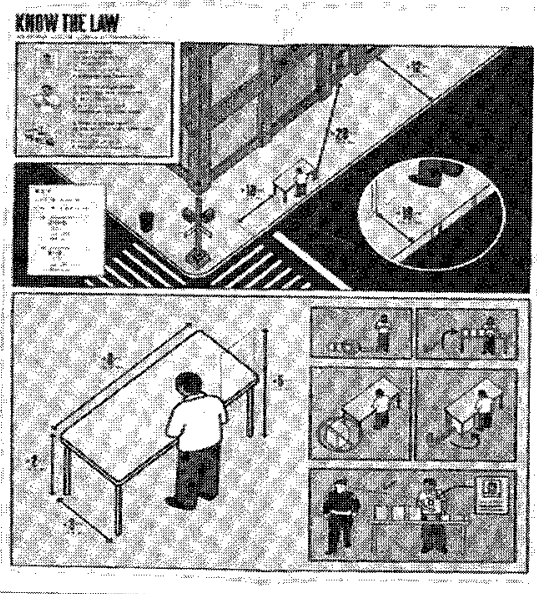

FIGURE 7. Example of Using Design to Communicate Legal Information-City Regulations Before and After ${ }^{184}$ [Color ligure can be viewed at wileyonlinelibraryom]

restricted streets. It's an uphill battle for vendors, whose interests have often been quashed by the City's "quality of life" crackdowns. 185

${ }^{194}$ See Vendor Powterf, supra note 188 (citing excerpts from Vendor Power: A GUTDE To STREeT VENDING IN NEW YORK CITY (2009), a visual guide to the rights and duties for street vendors in New York City. The book can be purchased or downloaded free from CUP Store) (used with permission).

${ }^{185}$ Chang, supra note 184. 
Consistent with our suggested Legal Design framework, the Street Vendor Project then identified a clear goal:

Our goal was to make an educational resource for vendors that clarifies the rules and their rights when confronted by police officers. We also wanted the poster to serve as an advocacy tool that highlights the history of vending, personal vendor stories, and policy reforms to help develop a more just system. ${ }^{186}$

The language and images needed to be simple, and to adapt to multiple audiences, many of whom struggled with English. ${ }^{187}$ This was achieved through strong collaboration between designers and users: "We learned more at The Street Vendor Project's monthly meeting where vendors join forces to inform each other about current issues and take an active role in making changes." 188

The design itself was iterative, with the goals, user needs, and legal functionality feeding back into a gradually evolving set of images. Here again is how Candy Chang described the process:

While learning about the challenges vendors face ... we started thinking about the content of the poster. How much would be directed towards street vendors as a much-needed resource, and how much would be an educational/advocacy tool about street vendors and regulation reform? How much would be about clarifying the convoluted regulations into clear graphics and how much would be about showing just how convoluted it currently is? ${ }^{189}$

The result was a graphic representation of the regulations that not only bolstered user knowledge and compliance, but may well have enhanced formal legal enforcement as well: "[The regulations] not only make it confusing for vendors but for the government too. Sean pointed out several tickets where even the police officers got the rules wrong." ${ }^{190}$ Chang concludes that "[c]ross-disciplinary collaboration is

\footnotetext{
${ }^{186} I d$.

187 "Today over $80 \%$ of NYC vendors in lower Manhattan are born outside the U.S., particularly Bangladesh, China, Senegal and Afghanistan." Id.

${ }^{188} I d$.

${ }^{189} \mathrm{ld}$.

${ }^{190} I d$.
} 
critical for combining approaches, looking at things differently and developing new solutions." 191

The Wikipedia Trademark initiative demonstrates how visual images and stronger attention to patterns of communication can strongly facilitate business as well as civic relationships. In the example below, the focus shifts away from strategies employed by the text designer and image creator, and even away from the separate attention to user needs. Instead, this example reveals how parties who are joined together through contracts or the law-transacting partners or citizens and states-can together be served through the imagery in contracts or regulations. Their relationships or joint interests, in other words, can be facilitated through the ability of visualization to promote collaboration as well as clarity and innovation, creativity, and better problem solving. The potential benefits are not confined to individual pairs of lawyer/client or contracting partners-better communication can facilitate stronger interactions throughout organizations. Such positive relationships have long been the goal of the PPL approach to lawyering and contracts, and, as illustrated below, are advanced through thoughtful use of visualization techniques. When parties to transactions collaborate, the entire process of communication-coding through de-coding and use of the documents-is not only more efficient, but also helps to generate broadly organizational and relational benefits.

Wikimedia Foundation introduced a trademark policy in 2009. In 2013, its legal team prepared a new draft trademark policy to strike a better balance between the interests of the Wikimedia community and trademark law, and to create a document that better communicates how people can use Wikimedia trademarks. ${ }^{192}$ In preparing their new draft document, the legal team relied on information design principles to make the draft

\footnotetext{
${ }^{191} I d$.

${ }^{192}$ See Yana Welinder, Call for Input on the New Trademark Policy, Wikimedia Blog (Nov. 18, 2013), https:/blog-wikimedia.org/2013/1 1/18/call-for-input-on-the-new-trademark-policy/ [hereinafter Call for Input]; see also Yana Welinder, 10 Days into Developing a Trademark Policy Through a Public Discussion, Yana's BloG; (Nov. 30, 2013), http://blogs.law.harvard.edu/yana/ ?p= 174; Yana Welinder \& Heather Walls, Designing a User-Friendly Trademark Policy for Some of the World's Most Recognizable Marks, Wikimfoia Biog; (Oct. 29, 2013), https://blog. wikimedia.org/2013/10/29/designing-a-user-friendly-trademark-policy/.
} 
user friendly. Simplicity of language, appearance, and format were several factors used to enhance its usability. The legal team also tried to organize the document in a logical manner so that users could quickly find provisions relevant to them without having to study the entire document. ${ }^{193}$

However, what makes the Wikimedia trademark policy truly revolutionary is the collaborative method for preparing it. In contrast to the manner in which lawyers typically prepare legal documents, the new draft policy was developed in public, "the Wiki way." The first step was for the legal team to solicit comments on how the policy should be revised and then prepare a draft based upon that feedback. They teamed up with legal information researchers and practitioners to organize two workshops called Legal Design Jams ${ }^{194}$ to brainstorm about how to make the policy more user-friendly, using colors, visuals, and other information design methods. ${ }^{195}$ The Legal Design Jams at Stanford and in San Francisco brought together professionals and students with law, design, computer science, and policy backgrounds to collaborate and learn together. Figure 8 displays an excerpt from their work, a visualized summary of the new draft trademark policy, asking the core question "May I use the Wikimedia marks?" and grouping the answers under traffic light colors: green for "Yes, please!" (use does not require permission); yellow for "Yes, but first ..." (permission must be sought); and red for "Sorry, no" (uses that are prohibited).

Next, the draft was posted on Wikimedia Meta-Wiki for feedback from the Wikimedia community across the world. The initial comments suggested that people liked the new design and found the document approachable and easy to read. According to Yana Welinder, one of

\footnotetext{
${ }^{193}$ Call for Input, supra note 198.

${ }^{19+}$ The idea of Legal Design Jams-a concept coined by Stefania Passera-is borrowed from "hackathons" and "service jams." A Legal Design Jam brings together people from different fields to "give an extreme user-centric makeover to a target legal document... to engage people to rethink and innovate the very concept of what a legal document should be, look and feel." See Ltcial. DESIG JAn, http://legaldesignjam.com (last visited Nov. 15, 2015); see also Haapio, supra note 2, at 451-58; Helena Haapio \& Stefania Passera, Visual Law: What Lauyers Need to Learn from Information Designers, Lrcin. INFo. INsi: (May 15, 2013), http://blog.law.cornell.edu/voxpop/2013/05/15/visual-law-what-lawyers-need-to-learnfrom-information-designers/; Margaret Hagan, 5 Insights from a Legal Design Jam, THF. WhIIEBOARD (Oct. 25, 2013), http://dschool.stanford.edu/fellowships/2013/10/25/5-insightsfrom-a-legal-design-jam/.
}

${ }^{195}$ See Call for Input, supra note 192; Welinder \& Walls, supra note 192. 


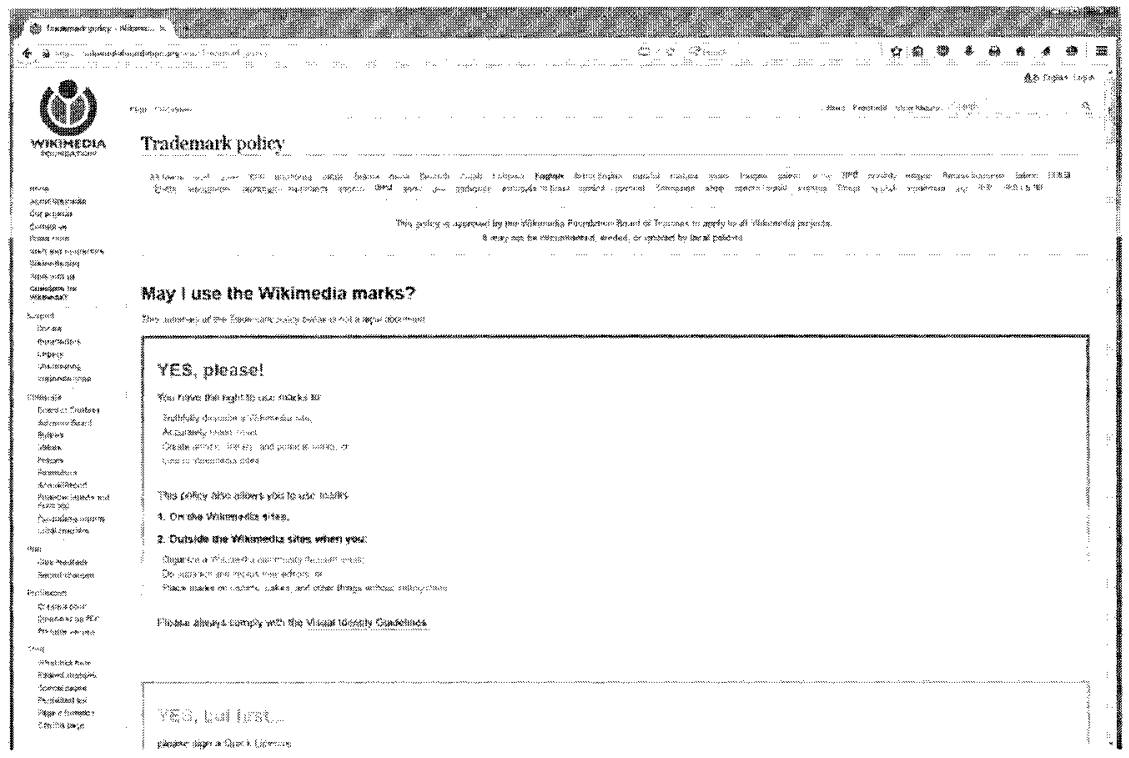

FIGURE 8. Excerpt from Wikimedia Trademark Policy. ${ }^{190}[$ Color figure can be viewed at wileyonlinelibrary.com]

Wikimedia Foundation's lawyers, the design and readability of the draft also improved the material discussion of the draft-people could get a better overview and understand the legal terms, so they could become involved in the discussion and comment on the substance of the terms. It helped them propose revisions or point out scenarios that were not yet addressed by the draft. ${ }^{197}$ This and the Street Vendor Project example above underscore the value of the collaborative design process for legal communication and problem solving.

\section{Conclusion}

"Legal Design" is a natural progression from recent efforts to incorporate visualization into legal texts. The interdisciplinary work needed to

\footnotetext{
${ }^{196}$ Used with permission. Wikimedia Foundation, CC BY-SA 3.0 (creativecommons.org/ licenses/by-sa/3.0), https:/wikimediafoundation,org/wiki/Trademark_policy (last visited May $5,2016)$.

${ }^{197}$ See Call for Inpul, supra note 192.
} 
enhance the clarity and usefulness of documents through images has brought together lawyers, managers, subject-matter experts, end users, and designers. Through that cooperation, a stronger appreciation of design principles may emerge-ideas that stress reflection and experimentation on the processes of creating legal visualization, as well as a concern for the end product. Such partnerships in legal design may, as suggested in this article, promote stronger collaboration and communication, creativity, and innovation, and perhaps paradoxically enhance the use of traditional legal analysis even as it helps to solve problems more effectively.

The investment in better, stronger Legal Design thus seems prudent. Even where it may require start-up expenses in coordinating designer work with legal professionals and business managers, that communication in itself may help to identify goals, smooth implementation, and prevent problems-all aims that have long been espoused by PPL. On many dimensions, further research into the development of Legal Design will promote positive outcomes and better business relationships. 